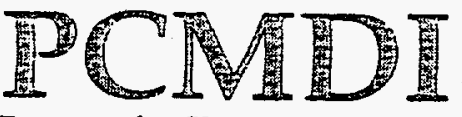

Program for Climate Model Diagnosis and Intercomparison

PCMDI Report No. 35

RECEIVED

AUG 021996

OSTI

STRUCTURE OF THE TROPICAL LOWER STRATOSPHERE AS REVEALED BY THREE REANALYSIS DATA SETS

\author{
by \\ Steven Pawson ${ }^{1}$ and Michael Fiorino ${ }^{2}$ \\ Institute for Meteorology \\ Free University of Berlin, Germany \\ ${ }^{2}$ Program for Climate Model Diagnosis and Intercomparison \\ Lawrence Livermore National Laboratory, Livermore, CA, USA
}

May 1996

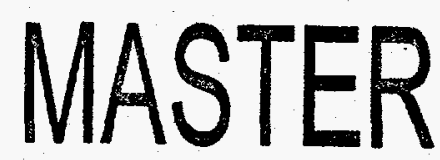

PROGRAM FOR CLIMATE MODEL DIAGNOSIS AND INTERCOMPARISON UNIVERSITY OF CALIFORNIA, LAWRENCE LIVERMORE NATIONAL LABORATORY LIVERMORE, CA 94550 


\section{DISCLAIMER}

This document was prepared as an account of work sponsored by an agency of the United States Government. Neither the United States Government nor the University of California nor any of their employees, makes any warranty, express or implied, or assumes any legal liability or responsibility for the accuracy, completeness, or usefulness of any information, apparatus, product, or process disclosed, or represents that its use would not infringe privately owned rights. Reference herein to any specific commercial product, process, or service by trade name, trademark, manufacturer, or otherwise, does not necessarily constitute or imply its endorsement, recommendation, or favoring by the United States Government or the University of Califomia. The views and opinions of authors expressed herein do not necessarily state or reflect those of the United States Government or the University of California, and shall not be used for advertising or product endorsement purposes.

This is an informal report intended primarily for internal or limited external distribution. The opinions and conclusions stated are those of the author and may or may not be those of the Laboratory.

This report has been reproduced directly from the best available copy.

Available to DOE and DOE contractors from the

Office of Scientific and Technical Information

P.O. Box 62, Oak Ridge, TN 37831

Prices available from (615) 576-8401, FTS 626-8401

Available to the public from the

National Technical Information Service

U.S. Department of Commerce

5285 Port Royal Rd.

Springfield, VA 22161 


\section{DISCLAIMER}

Portions of this document may be illegible in electronic image products. Images are produced from the best available original document. 


\title{
Structure of the Tropical Lower Stratosphere as Revealed by Three Reanalysis Data Sets
}

\author{
Steven Pawson ${ }^{1}$ and Michael Fiorino ${ }^{2}$ \\ ${ }^{1}$ Institute for Meteorology \\ Free University of Berlin \\ Germany \\ ${ }^{2}$ Program for Climate Model Diagnosis and Intercomparison \\ Lawrence Livermore National Laboratory \\ P.O. Box 808, L-264 \\ Livermore, CA 94551
}

Corresponding Author:

Dr. Michael Fiorino

Program for Climate Model Diagnosis and Intercomparison

P.O. Box 808 , L-264

Livermore, CA 94551

Phone: (510) 423-8505

Fax: $\quad(510) 422-7675$

email: fiorino@typhoon.Ilnl.gov 



\begin{abstract}
While the skill of climate simulation models has advanced over the last decade, mainly through improvements in modeling, further progress will depend on the availability and the quality of comprehensive validation data sets covering long time periods. A new source of such validation data is atmospheric "reanalysis" where a fixed, state-of-the-art global atmospheric model/data assimilation system is run through archived and recovered observations to produce a consistent set of atmospheric analyses. Although reanalysis will be free of non-physical variability caused by changes in the models and/or the assimilation procedure, it is necessary to assess its quality. That is, how good is reanalysis and how close should our climate models agree with these data.

A region for stringent testing of the quality of reanalysis is the tropical lower stratosphere. This portion of the atmosphere is sparse in observations but displays the prominent quasi-biennial oscillation (QBO) and an annual cycle, neither of which is fully understood, but which are likely coupled dynamically. We first consider the performance of three reanalyses, from NCEP/NCAR, NASA and ECMWF, against rawinsonde data in depicting the QBO and then examine the structure of the tropical lower stratosphere in NCEP and ECMWF data sets in detail.

While the annual cycle and the QBO in wind and temperature are quite successfully represented, the mean meridional circulations in NCEP and ECMWF data sets contain unusual features which may be due to the assimilation process rather than being physically based. Further, the models capture the long-term temperature fluctuations associated with volcanic eruptions, even though the physical mechanisms are not included, thus implying that the model does not mask prominent stratospheric signals in the observational data. We conclude that reanalysis offers a unique opportunity to better understand the dynamics of $\mathrm{QBO}$ and can be applied to climate model validation.
\end{abstract}




\section{INTRODUCTION}

The monitoring of climate and the understanding of atmospheric circulation require long-term data sets of the relevant meteorological variables. While a great deal of attention has been naturally focused on the surface and troposphere, the comprehensive validation of an increasing number of climate models requires a fuller understanding of the structure and dynamics of the stratosphere. However, the sparseness of observations in the stratosphere has prevented such comprehensive analyses. Some appropriate data sets for studying the long-term mean and variability come from the recent climatologies of COSPAR (1990), Randel (1992) and Pawson et al. (1993). The lower tropical stratosphere is still poorly understood as rawinsonde observations have relatively even poorer spatial coverage and satellite radiance measurements lack sufficient vertical resolution to capture the large shears of the zonal wind.

A promising new data source is from the meteorological "reanalysis" projects now underway at several centers (e.g., Kalnay and Jenne, 1991). These projects employ fixed and state-of-the-art global models and data assimilation systems to "reanalyze" all available observational data (operational as well as from archives and field campaigns) so as to produce a dynamically consistent, global description of the atmosphere over long time periods. Bengtsson and Shukla (1988) and Kinter and Shukla (1989) give a good discussion of the rationale behind reanalysis. However, even if reanalysis is considered (or defined) as the best source of data for climate model verification, prudence warrants a comparison against quasi-independent observations and other traditional data sets.

This report posits that the stratosphere is a good location for independent validation and we will focus on one aspect of the stratosphere that is thought to be important to climate processes -- the quasi-biennial oscillation (QBO). The QBO dominates the zonal wind in the tropical stratosphere (e.g., Naujokat, 1986) and is believed to be dynamically forced by the radiative dissipation of planetary-scale, tropical waves (Holton and Lindzen 1972), although other potential forcing mechanisms exist. The QBO affects planetary wave propagation in the middle atmosphere and is one factor responsible for interannual variability in the distribution of extratropical stratospheric ozone. There is also an important annual cycle in the lower stratosphere (e.g., Yulaeva et al. 1994) which may be coupled with the QBO (e.g., Dunkerton 1990).

In this study, we compare the Free University of Berlin (FUB) lower tropical stratosphere conventional data set (Naujokat 1986) to three meteorological reanalyses: 1) the National Centers for Environmental Prediction/National Center for Atmospheric Research (NCEP/NCAR), which is currently available from 1979 until 1995; 2) the Data Assimilation Office (DAO) of the NASA Goddard Space Flight Center for the period March 1985-September 1993; and 3) the European Centre for Medium Range Weather Forecasts (ECMIWF) Reanalysis project (ERA) for the period January 1979 - December 1990. 
However, the results must be treated with caution as they come from examining meteorological fields close to the upper boundaries of the numerical models used for the assimilation. Further, the tropical stratosphere may include fewer input data than other regions. While a successful representation of this region must be regarded as a benefit of the model, a poor simulation should not receive undue criticism.

The different data assimilation techniques and models used for the reanalysis projects are discussed in the following section. The successes of the reanalyses in simulating the tropical wind and temperature are examined in section 3. More detailed descriptions of the annual cycle and the QBO structure in the NCEP and ECMWF data sets are given in section 4. Finally, our work is summarized and possible future tasks are suggested in section 5 .

\section{DATA SETS}

Reanalysis contrasts with the conventional/traditional data sets (e.g., rawinsondeonly composites) in two fundamental ways: 1) an atmospheric general circulation model (AGCM) is an integral component of the analysis process; and 2) a wider range of observational data, including the rawinsondes, are employed. Thus, reanalysis not only provides potentially very useful dynamical quantities that cannot be determined by subjective analysis, but may in fact be more accurate than the benchmark traditional analyses, particularly in data sparse regions. However, the differences in the AGCM and analysis method will cause differences in the resulting reanalysis. These differences represent a source of unresolved uncertainty and one function of intercomparison is to better understand the magnitude and nature of this uncertainty.

Another point of difference between the reanalysis systems is the constraining boundary conditions on sea surface temperature (SST), sea ice concentration, soil moisture and even the earth-sun astronomy and concentration of radiatively important gases such as $\mathrm{CO}_{2}$. The NCEP/NCAR and ECMWF reanalyses use the same weekly SST and sea ice data, except for the period January 1979 - October 1981 when different versions of monthly mean data from the United Kingdom Meteorological Office (UKMO) Global sea Ice Sea Surface Temperature (GISST) data are used (Rayner et al. 1995 and Parker et al., 1995). The NASA reanalysis uses older monthly mean data from the NCEP Climate Prediction Center (CPC) and the Center for Ocean-Land-Atmosphere interactions (COLA). Table 1 summarizes some of the key differences between the three reanalyses that could impact the analysis of the tropical stratosphere.

\section{a. FUB rawinsonde compilation}

A compilation of monthly-averaged rawinsonde data at 70,50,40,30,20, 15 and $10 \mathrm{hPa}$ was presented by Naujokat (1986). Since the middle 1970 s this sets consists of data from one station, Singapore $\left(\sim 1^{\circ} \mathrm{N}, 102^{\circ} \mathrm{E}\right)$. It has been updated in Pawson et al. (1993) and has been used in many studies of the QBO, such as Wallace et al. (1993) and 
Fraedrich et al. (1993). It is used as a baseline reference data set here and to the extent that the Singapore soundings were used in reanalysis is considered quasi-independent.

\section{b. NCEP/NCAR reanalyses}

Aspects of the NCEP/NCAR reanalysis project are described in detail by Kalnay and Jenne (1991) and Kalnay et al. $(1993,1996)$. Sources of observational data include: 1) COADS surface marine data; 2) the rawinsonde network; 3) aircraft data; 4) satellite soundings (the TOVS sounders from 1979 onwards); and 5) satellite cloud drift winds. Extensive quality control is performed and a detailed record of all modifications to the observations as they pass through the system is maintained.

The AGCM forecast model component of the NCEP/NCAR reanalysis is described by Kanamitsu (1989) and Kanamitsu et al. (1991). It includes parameterizations of all important physical processes and in its T62/L28 configuration has five levels in the atmospheric boundary layer and ten levels above $200 \mathrm{hPa}$ with an upper boundary at $\sigma=$ .0273 or slightly lower than $3 \mathrm{hPa}$ (Kalnay et al. 1996). Postprocessed data at 17 pressure levels $(1000,925,850,700,500,400,300,250,200,150,100,70,50,30,20,10$ $\mathrm{hPa}$ ) were available for our study. Thus, the lower stratosphere is quite well resolved in both the model and the postprocessed data files.

\section{c. The NASA DAO reanalysis}

The DAO data assimilation system is documented by Pfaendtner et al. (1995) and Schubert et al. (1993 and 1995). It comprises a numerical model with 20 levels with the upper boundary at $20 \mathrm{hPa}$ and a $2.0 \times 2.5^{\circ}$ horizontal resolution. Seven of the levels (20, $30,50,70,100,150$, and $200 \mathrm{hPa}$ ) are in the stratosphere so the DAO AGCM does extend as high as in the NCEP reanalysis. Thus, it is a stringent test of this system to examine its performance near the upper boundary and the results must be respected in that an alternative model/assimilation system is used at DAO for stratospheric analyses. A description of the model can be found in Takacs et al. (1994).

Extensive quality control is performed on the input data (see Pfaendtner et al., 1995), which come from various sources, both ground- and satellite-based. The data are available from Mar 1985 until Oct 1993. A unique feature of the DAO reanalysis is the "incremental analysis update" in which the forecast state of the atmosphere from the AGCM is continuously adjusted to an optimal interpolation analysis of the observations. Thus, "shocks" to the analyzed atmosphere from instantaneous insertion of observations every 6-h as in the NCEP/NCAR and ECMWF systems are avoided at the cost of relaxing the closeness of the resulting analysis to the observations. 


\section{d. The ECMWF reanalysis (ERA)}

As in the other two reanalyses, ERA used similar input observational data. From Kallberg (1995), these data include: 1) GTS winds; 2) FGGE and ALPEX level-IIB data sets; 3) NESDIS cloud-cleared radiance data; 4) atmospheric data from COADS; 5) additional rawinsonde data; 6) GMS cloud-track wind data; 7) PAOB (Australian bogus) surface pressure data; 8 ) sea surface temperature data (monthly-means from the UKMO from 1979-Oct. 1991, thereafter weekly analyses from the CPC); and 9) weekly sea-ice concentration. However, unlike the NCEP/NCAR and DAO reanalyses, ERA uses a 1-D variational procedure to directly assimilate cloud-cleared satellite radiances into the temperature and moisture fields. Thus, the ERA data may show substantial differences with the other two reanalyses in fields sensitive to the thermodynamic structure of the atmosphere. Further, clouds are predicted in the ERA model instead of diagnosed as in the other reanalyses.

A stringent quality control is applied to the data before their use in the assimilation system. The data analysis is performed with optimal statistical interpolation and a 6hourly cycling (as in the other three reanalyses) and a diabatic, non-linear normal mode initialization are used. In contrast, neither the DAO or NCEP/NCAR system uses initialization and this could be another source of difference between ERA and the other data sets, particularly in the tropics. Additionally, the forecast model in ERA has the highest resolution in the horizontal (T106 or $\sim 100 \mathrm{~km}$ grid spacing) and in the vertical ( 31 hybrid [ $\sigma$-pressure] levels extending to $10 \mathrm{hPa}$ ). Currently, the data are available from 1979 until the end of 1990. 
Table 1. Features of the Three Reanalyses (INIT stands for initialization and BCS for boundary conditions on sea surface temperature and sea ice concentration). $R$ is the ratio of reanalysis model horizontal resolution to that in the ECMWF reanalysis

\begin{tabular}{|c|c|c|c|c|c|}
\hline REANAL & AGCM & $\begin{array}{c}\text { DATA } \\
\text { PERIOD }\end{array}$ & $\begin{array}{l}\text { ANALYSIS } \\
\text { METHOD }\end{array}$ & INIT & $\mathrm{BCS}$ \\
\hline NCEP/NCAR & $\begin{array}{l}\mathrm{T}: 62 / \mathrm{L} 28(\sigma) \\
\Delta x \sim 208 \mathrm{~km} \\
\mathrm{R}: 1.66\end{array}$ & $7901-9602$ & $\begin{array}{l}\text { Spectral } \\
\text { Statistical } \\
\text { Interpolation } \\
\text { (SSI) }\end{array}$ & none & $\begin{array}{l}\text { GISST2.2 EOF } \\
\text { reconstruct } \\
\text { (monthly) } \\
\text { Reynolds OI } \\
\text { (weekly) } \\
\text { Nomura sea ice }\end{array}$ \\
\hline ERA & $\begin{array}{l}\mathrm{T}: 106 / \mathrm{L} 3 \mathrm{l}(\sigma-\mathrm{p}) \\
\Delta x \sim 125 \mathrm{~km} \\
\mathrm{R}: 1.00\end{array}$ & $7901-9012$ & $\begin{array}{l}\text { Optimal } \\
\text { Interpolation } \\
\text { (OI) } \\
\text { IDVAR }\end{array}$ & $\begin{array}{l}\text { nonlinear } \\
\text { normal } \\
\text { mode (5 } \\
\text { modes) }\end{array}$ & $\begin{array}{l}\text { GISST } 2.0 \\
\text { (monthly) } \\
\text { Reynolds OI } \\
\text { (weekly) } \\
\text { Nomura sea ice }\end{array}$ \\
\hline NASA/DAO & $\begin{array}{l}\mathrm{G}: 2 \times 2.5^{\circ} / \mathrm{L} 20 \\
(\sigma) \\
\Delta x \sim 250 \mathrm{~km} \\
\mathrm{R}: 2.00\end{array}$ & $8503-9309$ & $\begin{array}{l}\text { OI and } \\
\text { Incremental } \\
\text { Analysis } \\
\text { Update (IAU) }\end{array}$ & none & $\begin{array}{l}\text { CPC/COLA } \\
\text { monthly means; } \\
\text { specified soil } \\
\text { moisture }\end{array}$ \\
\hline
\end{tabular}

\section{DATA COMPARISON IN THE TROPICAL STRATOSPHERE}

\section{a. Comparisons of the zonal wind}

Since the QBO dominates the zonal velocity between about 70 and $10 \mathrm{hPa}$, it is important to examine how it is captured by the reanalyzed data sets. The structure of the QBO has been documented by Naujokat (1986) using monthly averages of rawinsonde observations at Singapore $\left(1^{\circ} \mathrm{N}, 103^{\circ} \mathrm{E}\right)$, as well as two other stations for earlier years; these data (as updated in Pawson et al., 1993) are used as a reference here. They are available at 10, 15, 20, 30, 40,50 and $70 \mathrm{hPa}$. For the comparison, the nearest gridpoint to Singapore $\left(1.25^{\circ} \mathrm{N}, 102.5^{\circ} \mathrm{E}\right)$ in the reanalyses was used. Zonal averages are also shown for the NCEP data.

Fig. 1 demonstrates that the reanalyses capture QBOs of approximately the same phase and amplitude as the Singapore observations at all four levels. However, there are quantitative discrepancies between all of the data sets, which are discussed here with the aid of the differences shown in Figs. 2-4. The discussion begins with the NCEP data and concludes with the ERA data, and starts at $10 \mathrm{hPa}$ and works downwards.

At $10 \mathrm{hPa}$ there is some evidence that the westerly phase onset occurs later but more rapidly in the NCEP data than in the FUB analyses; this leads to large differences (sometimes exceeding $30 \mathrm{~ms}^{-1}$ ) at times when the rawinsonde observations are westerly but the NCEP data are still easterly (Fig. 2). The large error is compounded by the rapid 
transience and bimodality of the observed tropical winds (e.g., Naujokat 1986, Pawson et al. 1993). The strength of the maximum westerlies at $10 \mathrm{hPa}$ is underestimated somewhat (by up to $10 \mathrm{~ms}^{-1}$ ) in the NCEP data and some of the transients during the strong westerly phases is absent. In contrast, the transitions to the easterly extremes are generally well represented but they remain for too long.

Whereas at $10 \mathrm{hPa}$ there is an easterly bias in the NCEP data, there is a reverse bias at $30 \mathrm{hPa}$. Here, the transition to the westerly phase progresses quite well and the magnitudes of the westerlies (reaching about $15 \mathrm{~ms}^{-1}$ ) are similar in the two data sets but the easterlies in the NCEP data are persistently about $10 \mathrm{~ms}^{-1}$ weaker. At $50 \mathrm{hPa}$ the discrepancy between the two data sets is also evident. The transition from the westerly to the easterly wind regimes is much faster in the FUB composite data set and the difference between the easterly maxima is almost as large as the extrema in the NCEP data. By 70 $\mathrm{hPa}$ the biases are much smaller, although they can occasionally be as large as the wind extrema, e.g., from summer 1983 through summer 1984 the rawinsonde winds are persistently about $5 \mathrm{~ms}^{-1}$ stronger and in early 1990 and late 1993 the secondary easterly maxima are not captured in the NCEP data, leading to strong negative differences.

The NASA data, plotted at 70,50 and $30 \mathrm{hPa}$ in Fig. 1 are broadly similar to the NCEP data at $70 \mathrm{hPa}$, although they are somewhat more erratic (e.g., early 1988). At 30 and $50 \mathrm{hPa}$ the magnitude of the easterlies is underestimated quite considerably in most cases, leading to larger differences from the FUB data (Fig. 3) than the NCEP reanalyses showed. Differences at $20 \mathrm{hPa}$ (not shown) reveal that the oscillation in the data set is very weak there, resulting in differences which are almost as large as the Singapore winds in the rawinsonde observations.

While the ERA data exhibits a similar bias as in the NCEP reanalysis, we find much closer agreement at 30 and $50 \mathrm{hPa}$ and a slight easterly bias at $70 \mathrm{hPa}$ (Fig. 4). The 1-D variational assimilation of satellite radiances instead of temperature retrievals as in the NCEP reanalysis, may be the reason for the closer agreement; either because the resulting horizontal gradients in the temperature analysis were more consistent with the winds or because the rawinsonde data was given more weight. In general, the ERA gave the best representation of the QBO compared to the FUB data.

Finally, note that the zonal means of the NCEP data (Fig. 1) generally show weaker extrema and a smoother transient behavior than the grid-point values. The close agreement between the two curves supports the notion that the single station data represent the transient structure of the tropical lower stratospheric wind quite well.

\section{b. The seasonal march of wind and temperature}

There is an annual cycle in the winds and temperatures in the tropical lower stratosphere. The annual cycle in temperature was discussed by Yulaeva et al. (1994) using temperatures derived from the microwave sounding unit (MSU) satellite instrument. These temperatures are representative of a fairly deep layer in the lower stratosphere and 
Yulaeva et al. found peak-to-peak variations of about $4{ }^{\circ} \mathrm{C}$ averaged over the tropics. There is also an annual cycle in the zonal velocity, which is generally much weaker than the QBO, but uncertainty as to the interactions between the annual cycle and the QBO (e.g., Dunkerton 1990) remain, suggesting that the annual cycle may at least be partially an artifact of a seasonal modulation of the QBO.

The mean annual progression of the tropical winds (Fig. 5) reveals relatively good agreement between the three data sets, despite strong discrepancies in the mean over the available time periods. For instance, at $30 \mathrm{hPa}$ the long-term means are: $-6.9 \mathrm{~ms}^{-1}$ in the rawinsonde data, $-3.8 \mathrm{~ms}^{-1}$ in the NCEP data, and $-0.7 \mathrm{~ms}^{-1}$ in the NASA data and $-8.1 \mathrm{~ms}^{-1}$, but the annual march coincides to within one month and, at least in the maxima, to within $1 \mathrm{~ms}^{-1}$. The ERA winds are in especially close agreement at $30 \mathrm{hPa}$, but show interesting differences when the NASA and NCEP winds agree with each other (e.g., January at $50 \mathrm{hPa}$ ) and suggest differences in the treatment of the rawinsonde observations (e.g., bias correction in the heights above $200 \mathrm{hPa}$ ). Further, the NASA winds do not attain such strong negative values, consistent with the general westerly bias in that data set. Note that the averaging period is shorter than for the other data.

The mean seasonal march of tropical temperatures at $100 \mathrm{hPa}$ for the three reanalyses is shown in Fig. 6. The averaging periods are Jan 1979-Dec 1995 for NCEP, Jan 1986-Dec 1992 for NASA, and Jan 1979-Dec 1990 for ERA; tests showed that the precise choice of averaging period does not lead to significant changes in the differences found. The NCEP data show an annual cycle centered to the North of the equator; the temperature minimum is reached in December and January near $10^{\circ} \mathrm{N}$ and the maximum at this latitude exceeds $198.5^{\circ} \mathrm{K}$ in August (Fig. 6a). There is a clear interhemispheric asymmetry of the annual march of temperature at $100 \mathrm{hPa}$.

The difference between the NASA and NCEP data sets (Fig. 6b) shows that the NASA data are warmer north of about $10^{\circ} \mathrm{S}$ and cooler south of this latitude and that there is an annual dependence. The largest differences occur close to $15^{\circ} \mathrm{N}$ in October and November, suggesting slightly stronger descent or weaker ascent in that region at that time. With increasing altitude the NASA data become systematically colder than the NCEP data, the difference reaching about $7{ }^{\circ} \mathrm{C}$ at $20 \mathrm{hPa}$ in all seasons. This difference dominates the seasonal progression and displays annual and semi-annual components, the latter increasing with decreasing pressure.

At $100 \mathrm{hPa}$ the ERA temperatures are lower than those in the NCEP reanalyses (Fig. 6c). The difference has a semi-annual structure and is biased towards the Southern Hemisphere, thereby slightly reducing the interhemispheric asymmetry in the seasonal progression of the $100 \mathrm{hPa}$ temperature.

\section{c. The annual cycle in wind and temperature in NCEP and ERA data}

The annual cycles of the zonal-mean temperature and the horizontal velocity at 30 $\mathrm{hPa}$ are shown in Figs. 7 (NCEP) and 8 (ERA). In both data sets the temperature 
minimum occurs south of the equator in February but it is about $3.5^{\circ} \mathrm{K}$ lower in the ERA data. In the subtropics (at $30^{\circ} \mathrm{N}$ and $\mathrm{S}$ ) the differences are much smaller, so that the latitudinal curvature of the temperature is stronger in the ERA data. Consistently, the extreme easterlies are about $5 \mathrm{~ms}^{-1}$ faster in the ERA analyses (Figs. $7 \mathrm{~b}$ and $8 \mathrm{~b}$ ). Indeed, there is a general easterly bias in the ERA winds. The meridional velocity displays quite large differences between the two analyses. The NCEP analysis reveals a fairly strong northward bias to the flow, whereas the ERA data are much more symmetric between the hemispheres in the opposing seasons. Thus, in the NCEP analyses there is a strong net flow from the Southern to the Northern Hemisphere (Fig. 7c). This is further illustrated by the latitude-height cross-sections of $v$ (Fig. 9c and f), which clearly show that the northward flow in the tropics in DJF is generally about twice as strong as the southward flow in JJA at all levels. At $100 \mathrm{hPa}$ the differences are more extreme, presumably due to the stronger upward extension of the Hadley circulation in DJF. At 100 and $70 \mathrm{hPa}$ the temperature is about $5^{\circ} \mathrm{C}$ lower in DJF than in JJA, in good agreement with the results of Yulaeva et al. (1994), but these differences reduce to about $2.5^{\circ} \mathrm{C}$ at $10 \mathrm{hPa}$. The zonalmean zonal velocity is reasonably symmetric, although slightly stronger easterlies penetrate into the Southern Hemisphere in JJA than into the northern hemisphere in DJF.

While qualitative differences between the temperature and zonal wind can be seen in the NCEP and ERA reanalyses (Figs. 9 and 10), the meridional flow is much more symmetric between the seasons with a net northward flow in DJF being more closely balanced by the net southward flow in JJA. However, there is a far more pronounced two cycle $(+/ / t /-)$ variation in the ERA data suggesting differences in the treatment of the model upper boundary conditions, in gravity wave drag or in the orography itself. These differences in the meridional flow would presumably have a considerable impact on trace gas transport in the stratosphere.

\section{LOWER STRATOSPHERIC STRUCTURE RELATED TO THE QBO}

\section{a. Time development of the $Q B O$}

Wind and temperature anomalies associated with the QBO are presented using the NCEP and ERA data, as an extension of the time-series of Dunkerton and Delisi (1985). The long-term mean of the mean annual cycles were removed from the temperature and wind fields, thereby removing the weak seasonal march. Finally, the fields were smoothed to improve interpretation as the meridional wind, in particular, contained a large amount of high frequency noise. The resulting smoothed deseasonalized zonal and meridional winds at $30 \mathrm{hPa}$ (Fig. 11) show a clear QBO signal, with the velocity perturbation centered close to the equator, decaying to almost zero by $20^{\circ}$ in each hemisphere where the easterly maxima in the annual march of winds occurs (Fig. 7). The QBO thus defined displays winds which vary from almost $20 \mathrm{~ms}^{-1}$ in the strongest 
westerlies to more than $-20 \mathrm{~ms}^{-1}$ peak easterlies. There is considerable variability in the strength and the latitudinal structure of this QBO, as anticipated.

The closer agreement between the ERA data and the FUB analyses also appears in the corresponding deseasonalized data (Fig. 12), where the peak velocities are stronger than in the NCEP data (Fig. 11). Visually, the ERA-QBO is slightly noisier than the corresponding NCEP time series. The meridional velocities in both data sets are quite noisy but a relationship with the $\mathrm{QBO}$ is apparent, with opposing motions on each side of the equator, in qualitatively good agreement with the model study of Plumb and Bell (1982), who found that the QBO-induced mean meridional circulation acted to reinforce the thermal wind balance associated with the shear zones. There is clearly much higherfrequency (several months) variability in the meridional velocity in both data sets, but note the increased amplitude of the high frequencies during transitions in the NCEP reanalyses (Fig. 11). This feature may be a further indication of differences in wave propagation in the two models.

The temperature anomalies associated with the $\mathrm{QBO}$ are generally out of phase between the equator and around $20^{\circ}$ latitude, a consequence of the mean meridional circulation anomalies associated with the QBO (Plumb and Bell 1982), with cold anomalies occurring at the equator in the transition from easterly to westerly wind regimes. These temperature anomalies are clearly seen in Figs. 13b (NCEP) and 14b (ERA), where not only the annual cycle but also the mean temperature anomaly in the tropics (Figs. 13a and 14a) were removed. The resulting QBO-temperature anomalies agree quite well but, again, the magnitudes of the extrema are larger in the ERA data.

The reason for the removal of the anomalies across the entire tropical region (e.g., Labitzke et al. 1983) is the effects of the two major volcanic eruptions El Chichón in April 1982 and Mt. Pinatubo in June 1991, which led to warming across the entire tropical region. These anomalies appear as warmings of around $2^{\circ} \mathrm{C}$ in the NCEP data (Fig. 13a) and (for El Chichón) about $3{ }^{\circ} \mathrm{C}$ in the ERA data (Fig. 14a). As discussed by Dunkerton and Delisi (1985) the warm anomaly associated with the QBO is strengthened in the latter part of 1982 and 1983. In 1991-1992 the cold anomaly of the QBO is hidden by the warm anomaly arising from Pinatubo. It is remarkable that the reanalyses have captured these volcanically induced temperature anomalies as the necessary changes to the physical forcing were not incorporated into either model (i.e., the changes in radiative . forcing arising from the aerosol loading of the stratosphere). Thus, the model did not contaminate the volcanically forced signals in the observations.

\section{b. Composites of the $Q B O$}

Composites have been made for the $\mathrm{QBO}$ based on transitions at $30 \mathrm{hPa}$. These are shown for the seven transitions (see Table 2) for the NCEP data (Fig. 15). Note that these were determined from the deseasonalized data (i.e. the mean annual cycle was removed) and that the transition months were defined as the month during the changeover where the velocity was closest to zero. Concentrating first on the zonal velocity, the two 
transitions show the expected behavior. In the E-W transition at $30 \mathrm{hPa}$ the easterlies in the lower stratosphere reach almost $10 \mathrm{~ms}^{-1}$ at $50 \mathrm{hPa}$ while a strong westerly jet is apparent at lower pressures.

Table 2. The transition months for the deseasonalized zonal-mean $30 \mathrm{hPa}$ velocity at the equator calculated for the NCEP and ERA analyses. (Note: These were the months closest to the transitions. Also, in both data sets there was a W-E transition in March 1979 which was not used.)

\begin{tabular}{||l|l|l|l|}
\hline \multicolumn{2}{|c|}{ E-W TRANSISTION } & \multicolumn{2}{c|}{ W-E TRANSITION } \\
\hline \multicolumn{1}{|c|}{ NCEP/NCAR } & \multicolumn{1}{|c|}{ ERA } & \multicolumn{1}{c|}{ NCEP/NCAR } & \multicolumn{1}{c|}{ ERA } \\
\hline Mar 1980 & Feb 1980 & Aug 1981 & Jun 1981 \\
\hline Jul 1982 & Jul 1982 & Aug 1983 & Jul 1983 \\
\hline Jan 1985 & Dec 1984 & Jul 1986 & Jun 1986 \\
\hline Jul 1987 & Jul 1987 & Nov 1988 & Nov 1988 \\
\hline Mar 1990 & & Jun 1991 & \\
\hline Aug 1992 & & Oct 1993 & \\
\hline Nov 1994 & & Nov 1995 & \\
\hline
\end{tabular}

Both wind regimes are somewhat weaker in the W-E transition but their structures are quite similar, being symmetric about the equator and decaying with a half width of about $15^{\circ}$, in good agreement with traditional observations (e.g., Wallace 1973). If only the first four cases are used in the NCEP composites, each of the major wind jets is slightly stronger than in the composite over seven cases. However, the increased strength of the lower stratospheric winds is not as large as those in the ERA data, which is also composited from four cases. The composite maximum easterlies reach $17.5 \mathrm{~ms}^{-1}$ at 50 $\mathrm{hPa}$, about twice as strong as in the NCEP data, while the lower stratospheric westerly jet at the time of the W-E transition exceeds $7.5 \mathrm{~ms}^{-1}$ in the ERA data compared to $2.5 \mathrm{~ms}^{-1}$ in the NCEP composite. The magnitudes of these lower-level jets are thus much more realistic in the ERA data than in the NCEP data (compare with Pawson et al. 1993, p. 284). In contrast, the upper-level extrema are weaker and less realistic in the ERA than in . the NCEP data.

Turning to the temperature anomalies for the two composites (Figs. 15 and 16), it is clear that for the E-W transition the two data sets show positive anomalies of approximately the same strength at $30 \mathrm{hPa}$ on the equator, but that the meridional gradient, particularly into the Southern Hemisphere, is slightly stronger in the ERA data. Again, this does not depend on the use of four instead of seven transitions in the NCEP analysis. These temperature anomalies are consistent with those in the idealized models of the QBO (e.g., Plumb and Bell 1982), since the anomalous descent on the equator in 
the westerly shear zone implies more adiabatic warming in that region, with regions of reduced adiabatic warming located off the equator, which are clearly seen in the temperature minima between $10-20^{\circ}$ in each hemisphere.

The northward velocity anomalies associated with this QBO-induced meridional circulation cell are evident for the NCEP data (Fig. 15): there is a strong convergence towards the equator just above the temperature maximum with a divergence below this level. This is in good agreement with such idealized studies as the model of Plumb and Bell (1982) and with the meridional motions inferred from satellite measurements of aerosol distributions by Trepte and Hitchman (1992).

The meridional circulation anomalies were calculated from the raw data in the following manner. First, the data were deseasonalized, so that the mean annual cycle ought to be removed. The QBO signal was still not immediately clear, because of the large-scale cross equatorial flow which varies in strength from year to year. This flow is particularly acute for the NCEP data as already discussed, and can clearly be seen on the upper left panels of Figs. 17 and 18, each of which show a clear increase of the strength of the northward flow from the Southern into the Northern Hemisphere. Deseasonalizing these data removes this large-scale flow, leaving approximately the correct interhemispheric asymmetry for the two QBO transition zones, but a hint of the general northward flow remains. The northward flow was thus "deconvolved" into two components, a large-scale northward flow and a remainder, which should represent the equatorially anti-symmetric anomaly associated with the $\mathrm{QBO}$. This deconvolution was performed quite crudely in this study: the mean over the $30 \mathrm{~N}-30 \mathrm{~S}$ latitude range was simply subtracted from the total at each latitude. The qualitatively correct appearance of the anomalies in Fig. 15 suggests that this method is quite successful for the NCEP data.

The meridional circulation anomalies in the ERA analyses do not agree so well with expectations. Although Fig. 16 shows some hint of the correct asymmetries close to $30 \mathrm{hPa}$, they are by no means as large or as asymmetric as those for the NCEP data (Fig. 15). Given that the temperature anomalies in the E-W transition have about the same magnitude in each data set, this is surprising. The situation is worse for the easterly shear zone in the W-E transition, where the negative temperature anomaly of $3.5^{\circ} \mathrm{K}$ at $30 \mathrm{hPa}$ is more than twice as large as that in the NCEP data (Fig. 15) but the corresponding northward flow anomalies are difficult to see in the ERA data. In both cases of transition at $30 \mathrm{hPa}$, the anomalies in the mean meridional circulation in the NCEP data almost fill the regions between 70 and $10 \mathrm{hPa}$ with their double-celled structure (horizontal convergence above divergence, and vice versa), while the ERA reanalysis shows a much more detailed structure at lower levels: specifically, a much stronger meridional cell exists near $50 \mathrm{hPa}$ than in the upper stratosphere and there are corresponding changes in the temperature near $50 \mathrm{hPa}$. This cell also has a vertical scale of approximately one data point (opposite-directed anomalies at 50 and $70 \mathrm{hPa}$ ) and, as such, is an uncertain feature of the reanalysis. Even though the mean annual cycle of $\mathrm{v}$ appears to be better represented in the ERA than in the NCEP reanalyses, it appears that the QBO-associated meridional circulation is better captured by the NCEP data. This is further confirmed by a 
closer examination of the northward flow in Figs. 17 and 18, where the ERA analyses in the individual transitions at $30 \mathrm{hPa}$ show much variability in strength and direction between each case, unlike the NCEP data.

In summary, it appears that the ERA data portrays a more realistic lower stratospheric winds in each phase of the QBO than the NCEP analysis. In the upper stratosphere the situation is reversed and the ERA winds are too weak. The temperature anomalies are well captured by both data sets, although they have slightly higher magnitude in the ERA data. The QBO-associated anomalies in the NCEP data appear to be much more realistic, in that they agree with those from simple numerical models and those implied from observations, while the ERA data do not agree well with reality.

\section{SUMMARY AND DISCUSSION}

In this study, the ability of three reanalysis systems to reproduce the observed QBO at Singapore as derived from rawinsonde observations (Naujokat 1986) has been discussed. Generally, the NCEP and ERA reanalyses performed better than the NASA system, possibly because the upper boundary of the NCEP and ERA models is higher than that of the NASA model, although many other factors could affect the results. The NCEP data generally show a westerly bias at 30 and $50 \mathrm{hPa}$ and are unable to reach the extreme easterlies found in rawinsonde data, but at $10 \mathrm{hPa}$ they show the opposite problem. They also tended not to transform into the westerly state until several months after the rawinsonde data, leading to extremely large errors when the rawinsonde data already showed an easterly phase but the reanalysis remained westerly. The NASA data were not so successful, since they did not attain appropriate magnitudes of either extreme at 30 $\mathrm{hPa}$ and failed to turn sufficiently to the easterlies at $50 \mathrm{hPa}$. At $70 \mathrm{hPa}$ both analyses show more short-term variability than the rawinsonde data. The ERA data generally showed better agreement with the rawinsonde composites than the NCEP reanalyses, especially at 30 and $50 \mathrm{hPa}$.

Composites of the latitude-height structure of the QBO during its phase transitions at $30 \mathrm{hPa}$ for the NCEP and ERA data revealed the expected structures, with strong vertical wind shears and associated temperature and meridional velocity anomalies. These composites are consistent with the simple model results of Plumb and Bell (1982) and the meridional circulations deduced from stratospheric aerosol data by Trepte and Hitchman (1992).

In addition to the QBO, there is an important annual cycle in the wind and temperature of the lower stratosphere. All three reanalyzed data sets produced an annual cycle in the zonal wind which is in broad agreement with that in the rawinsonde data at Singapore. The mean annual march of temperatures was also discussed; in the NCEP and ERA data there is a clear annual cycle at all levels, in good agreement with that found by Yulaeva et al. (1994). The NASA data differ from the NCEP data in that they become increasingly cold with decreasing pressure. At $100 \mathrm{hPa}$ there is an interhemispheric 
asymmetry in the difference, NCEP data being warmer south of $20^{\circ} \mathrm{S}$ but colder elsewhere. The ERA data are colder than the NCEP data throughout the tropical lower stratosphere, the magnitude of the difference decreasing from the equator to the subtropics. Curiously, the ERA data are much more symmetric with respect to the equator than the NCEP data, which show a bias towards northward meridional flow throughout the year.

Beyond the annual and quasi-biennial signals, a strong low-frequency variability is evident in the temperature field, with latitude-independent warming in the tropics following the two major volcanic eruptions. This signal is stronger than the magnitude of the $\mathrm{QBO}$. We also found some high-frequency variability in the tropical temperatures and meridional winds.

There are probably three major results of the intercomparison presented in this study: the ability of all three models to represent the QBO but especially the dominant wind oscillation in the ERA data; the large-scale warming which is captured by the reanalyses following volcanic eruptions; and the considerable differences in the meridional velocities associated with the annual and quasi-biennial cycles. All three of these features deserve further, more detailed study.

It is well known that current GCMs are not capable of simulating a QBO when run without any relaxation towards observations (Pawson 1992; Hamilton and Yuan 1992). Thus, the forcing mechanisms for the QBO in the reanalyses deserve detailed study: is the QBO forced by tropical waves or is it simply there because of the constant input of observations into the reanalyses? Further, the observed QBO is known to be influenced by factors external to the tropical lower stratosphere, especially the annual cycle (Dunkerton 1991; Kinnersley and Pawson 1996), which have been studied in simplified numerical models. The current data sets could facilitate a full examination of the forcing mechanisms and also help answer the question of whether the quasi-biennial and annual cycles in the lower stratosphere are dynamically linked. The deseasonalization of the data in this study implicitly assumes only a linear combination of the two cycles --- this may not be valid if dynamical connections are present.

Extensions of this work include the possibility of a full analysis of the dynamics of the $\mathrm{QBO}$, which may isolate the forcing mechanisms of the oscillation and a closer examination of the annual cycle in the NCEP and ERA models. These would both involve examination of the daily data, rather than the monthly-means used in the current study.

Finally, the differences between the meridional velocities are intriguing and (at least at first sight) contradictory. In both the seasonal means and the QBO composites, the northward velocity in the ERA data displayed some small-scale vertical structure which may be unrealistic. It is important to investigate whether this arises from. say inertial instabilities in the model or from constraints placed on the model fields by the assimilation process. 
In summary, this study has presented a 'first look' at the annual and quasi-biennial cycles of the tropical lower stratosphere in three reanalysis products. Some very successful aspects of the data sets have been found, but there are also some apparent deficiencies which ought to be understood before similar projects are undertaken in the future.

Acknowledgments. We are grateful to the staff of the three research centers who kindly provided the reanalysis data and Barbara Naujokat (FUB) for the rawinsonde analyses. Larry Gates provided generous support for SP during his visit to PCMDI.

This work was sponsored in part by the U.S. Department of Energy Environmental Sciences Division and performed by the Lawrence Livermore National Laboratory under Contract No. W-7405-Eng-48. 


\section{REFERENCES}

Bengtsson, L. and J. Shukla, 1988: Integration of space and in situ observations to study global climate change. Bull. Am. Meteorol. Soc., 69, 1130-1143.

Dunkerton, T.J., 1990: Annual variation of deseasonalised mean flow acceleration in the equatorial lower stratosphere. J. Meteorol. Soc. Jpn., 68, 499-508.]

Dunkerton, T.J., 1991: Nonlinear propagation of zonal winds in an atmosphere with Newtonian cooling and equatorial wave driving. J. Atmos. Sci., 48, 236-263.

Dunkerton, T.J. and D.P. Delisi, 1985: Climatology of the equatorial lower stratosphere. J. Atmos. Sci., 42, 376-396.

Fraedrich, K., S. Pawson, and R. Wang, 1993: An EOF analysis of the vertical-time-delay structure of the quasi-biennial oscillation. J. Atmos. Sci., 50, 3357-3365.

Kallberg, P., 1995: ECMWF reanalysis project. Proceedings of the Twentieth Annual Climate Diagnostics Workshop, 23-27 October, 1995, Seattle.

Hamilton, K.P., and L. Yuan, 1992: Experiments on tropical stratospheric mean wind variations in a spectral general circulation model. J. Atmos. Sci., 49, 2464-2583.

Kalnay, E., and R. Jenne, 1991: Summary of the NCEP/NCAR reanalysis workshop of April 1991. Bull. Am. Meteorol. Soc., 72, 1897-1904.

Kalnay, E., M. Kanamitsu, R. Kistler, W. Collins, D. Deaven, L. Gandin, S. Saha, G. White, J. Woolen, M. Chelliah, J. Janowiak, K.C. Mo, J. Wang, A. Leetma, R. Reynolds, R. Jenne, E. Kung, and D. Salstein, 1993: The NCEP/NCAR CDAS/reanalysis project. NCEP Office Note 401.42 pp. [Available from NOAA/NCEP, 5200 Auth Rd., Washington, DC 20233.]

Kalnay, E., M. Kanamitsu, R. Kistler, W. Collins, D. Deaven, L. Gandin, M. Iredell, S. Saha, G. White, J. Woolen, Y. Zhu, M. Chelliah, W. Ebisuzaki, W. Higgins, J. Janowiak, K.C. Mo, C. Ropelewski, J. Wang, A. Leetma, R. Reynolds, R. Jenne, and D. Joseph, 1996: The NCEP/NCAR 40-year reanalysis project. Bull. Am. Meteorol. Soc., 77, 437-471.

Kanamitsu, M., 1989: Description of the NCEP global data aassimilation and forecasting system. Forecasting, 4, 334-342.

Kanamitsu, M., J.C. Alpert, K.A. Campana, P.M. Caplan, D.G. Deaven, M. Iredell, B. Katz, H.L. Pan, J. Sela, and G.H. White, 1991: Recent changes implemented into the global forecasting system at NCEP. NCEP Notes, 0001-0012.

Kinnersley, J.S. and S. Pawson, 1996: On the descent rates of the shear zones of the equatorial QBO. J. Atmos. Sci., 53, in press. 
Kinter, J.L., and J. Shukla, 1989: Reanalysis for TOGA (Tropical Oceans, Global Atmosphere). 1-3 February 1989 meeting at the Center for Ocean-LandAtmosphere Interactions. Bull. Am. Meteorol. Soc., 70, 1422-1427.

Labitzke, K., B. Naujokat, and M.P. McCormick, 1983: Temperature effects on the stratosphere of the April 4, 1982 eruption of El Chichon. Geophys. Res Lett., 10, 24-26.

Naujokat, J. 1986: An update of the observed quasi-biennial oscillation of the stratospheric winds over the tropics. J. Atmos. Sci., 43, 1873-1877.

Parker, D.R., M. Jackson and E.B. Horton, 1995: The GISST2.2 sea surface temperature and sea-ice climatology. Climate Research Tech Note No. 63, Hadley Centre for Climate Prediction and Research, Hadley Centre Internal Note No. 69. United Kingdom Meteorological Officer, Bracknell, U.K.

Pawson, S., Labitzke, K., Lenschow, R., Naujokat, B., Rajewski, B., Wiesner, M., and Wohlfart, R.-C., 1993: Climatology of the Northern Hemisphere Stratosphere Derived from Berlin Analyses. Part 1: Monthly Means. Meteorologische Abhandlung, Inst für Meteorologie der F. U. Berlin, Serie A, Band 7, Heft 3.

Pfaendtner, J., S. Bloom, D. Lamich, M. Seablom, M. Sienkiewicz, J. Stobie and A. da Silva, 1995: Documentation of the Goddard Earth Observing System (GEOS) Data Assimilation System - Version 1, NASA Tech. Mem. 104606, Vol. 4, NASA Goddard Space Flight Center, Greenbelt, MD.

Plumb, R.A., and R.C. Bell, 1982: A model of the equatorial quasi-biennial oscillation on an equatorial beta-plane. Q. J. R. Meteorol. Soc., 108, 335-352.

Rayner, N.A., C.K. Folland, D.E. Parker and E.B. Horton, 1995: A new global sea-ice and sea surface temperature (GISST) data set for 1903-1994 for forcing climate models. Hadley Centre Internal Note No. 69. United Kingdom Meteorological Office, Bracknell, U.K.

Schubert, S.D., J. Pfaendtner and R. Rood, 1993: An assimilated data set for Earth science applications, Bull. Am Meteorol. Soc., 74, 2331-2342.

Schubert, S.D., C.-K. Park, C.-Y. Wu, W. Higgins, Y. Kondratyeva, A. Molod, L Takacs, M. Seablom and R. Rood, 1995: A multiyear assimilation with the GEOS-1 system: overview and, NASA Tech. Mem. 104606, Vol. 6, NASA Goddard Space Flight Center, Greenbelt, MD, 207 pp.

Takacs, L., A. Molod, and T. Wang, 1994: Documentation of the Goddard Earth Observing System (GEOS) General Circulation Model - Version 1, NASA Tech. Mem. 104606, Vol. 1, NASA Goddard Space Flight Center, Greenbelt, MD.

Trepte, C.R., and M.H. Hitchman, 1992: Tropical stratospheric circulation deduced from satellite aerosol data. Nature, 355, 626-628. 
Wallace, J.M., 1973: General circulation of the tropical lower stratosphere. Rev. Geophys. Space Phys., 11, 191-222.

Wallace, J.M., R.L. Panetta, and J. Estberg, 1993: Representation of the equatorial stratospheric quasi-biennial oscillation in EOF phase space. J. Atmos. Sci., 50, $1751-1762$.

Yulaeva, E., J.R. Holton, and J.M. Wallace, 1994: On the cause of the annual cycle in tropical lower-stratospheric temperatures. J. Atmos. Sci., 51, 169-174. 


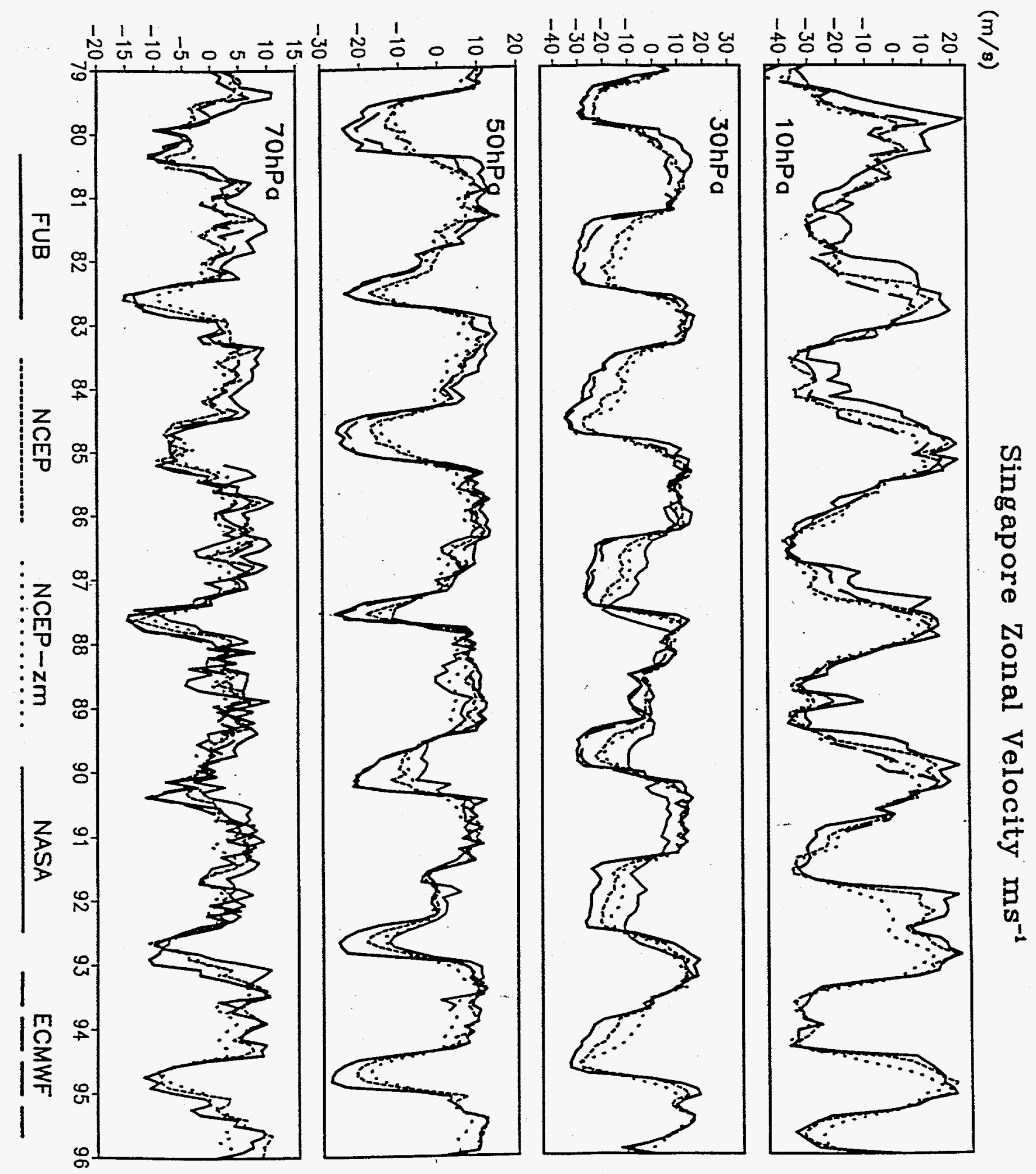

Fig. 1. The tropical winds at $10,30,50$, and $70 \mathrm{hPa}$. Monthly-averaged rawinsonde observations (Naujokat 1986; Pawson et al. 1993) from Singapore (thick solid line) are compared to the NCEP reanalyses at $1.25^{\circ} \mathrm{N}, 102.5^{\circ} \mathrm{E}$ (long thin dashes), the zonal-mean of these data (thin shor dashes, the NASA reanalyses (thin solid line) and ERA (thick long dashes). 

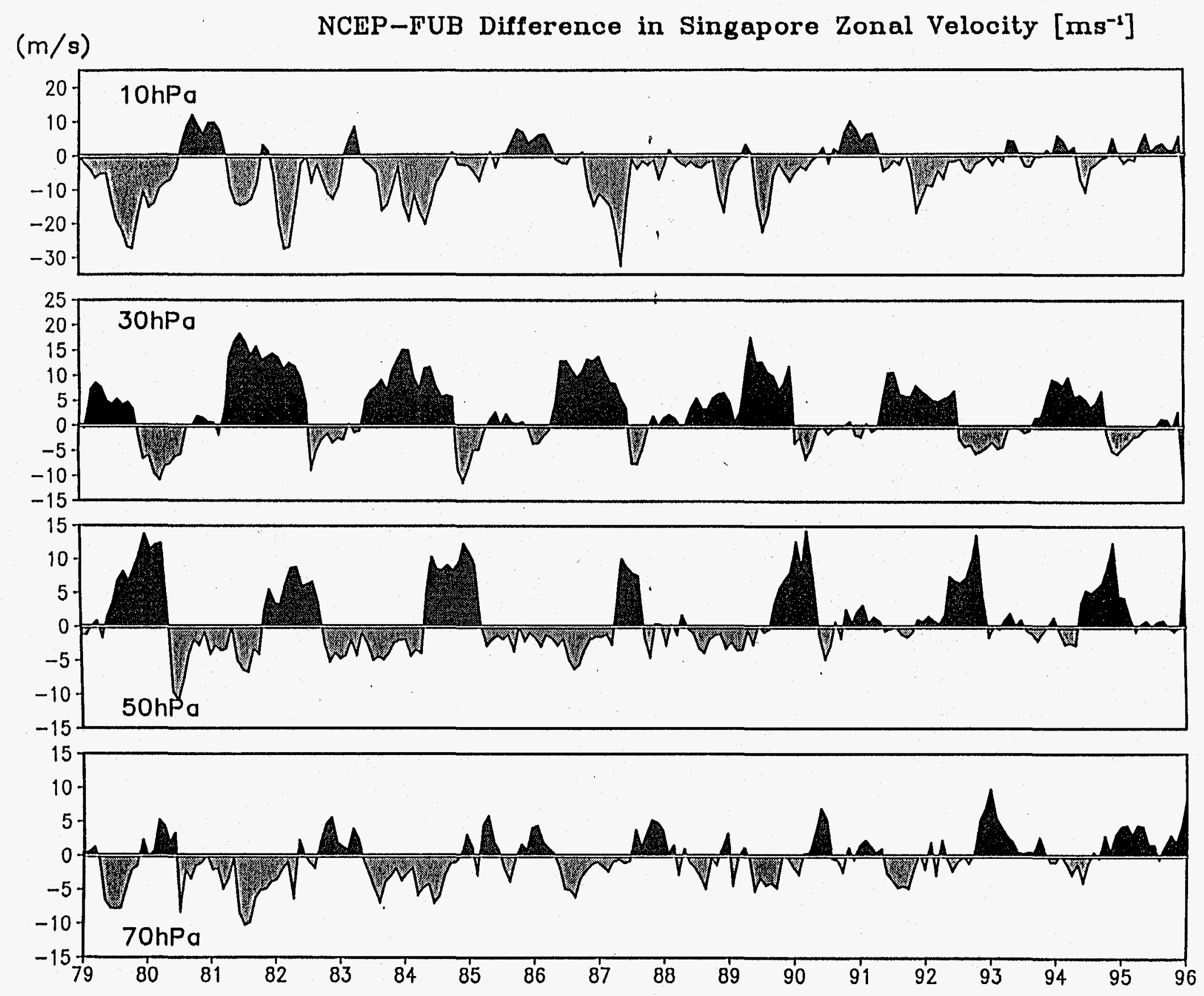


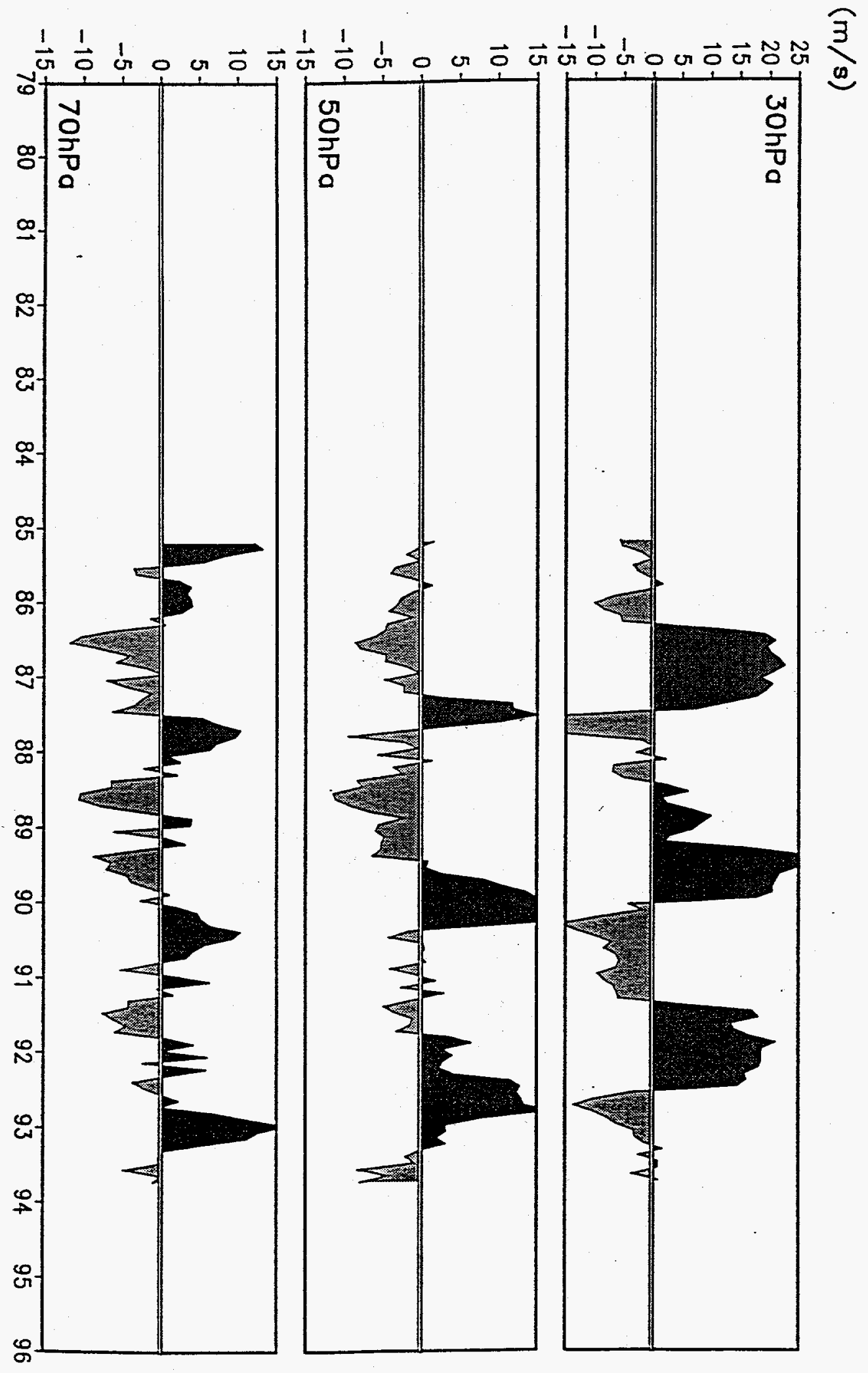

Z

Fig. 3. Differences between the rawinsonde observations and the NASA reanalyses at 20, 30, 50, and $70 \mathrm{hPa}$. Positive values mean that the rawinsonde observations are more westerly than the NASA data. 


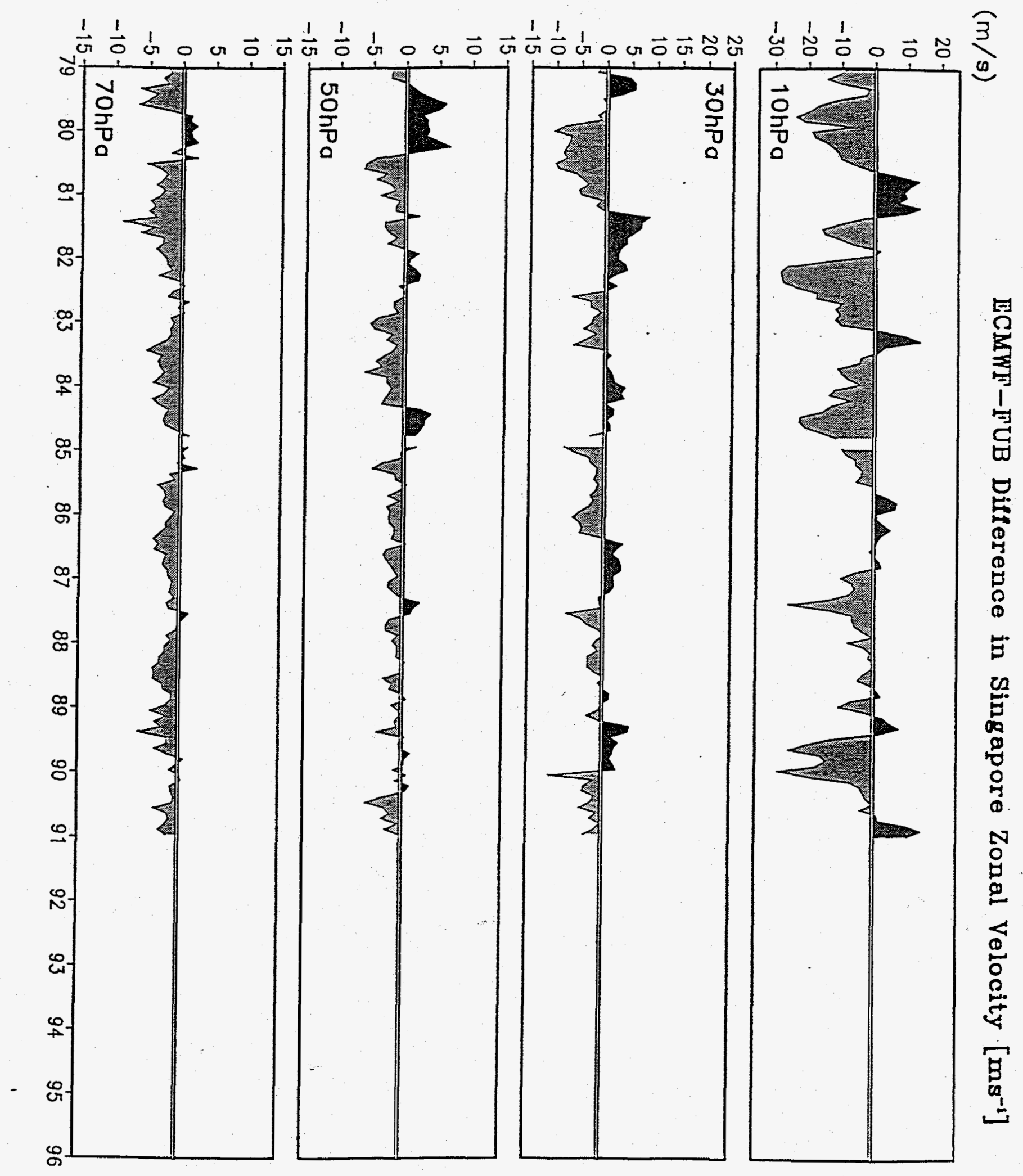

Fig. 4. Differences between the rawinsonde observations and the ERA reanalyses at 10,30,50, and $70 \mathrm{hPa}$. Positive values mean that the rawinsonde observations are more westerly than the NASA data. 


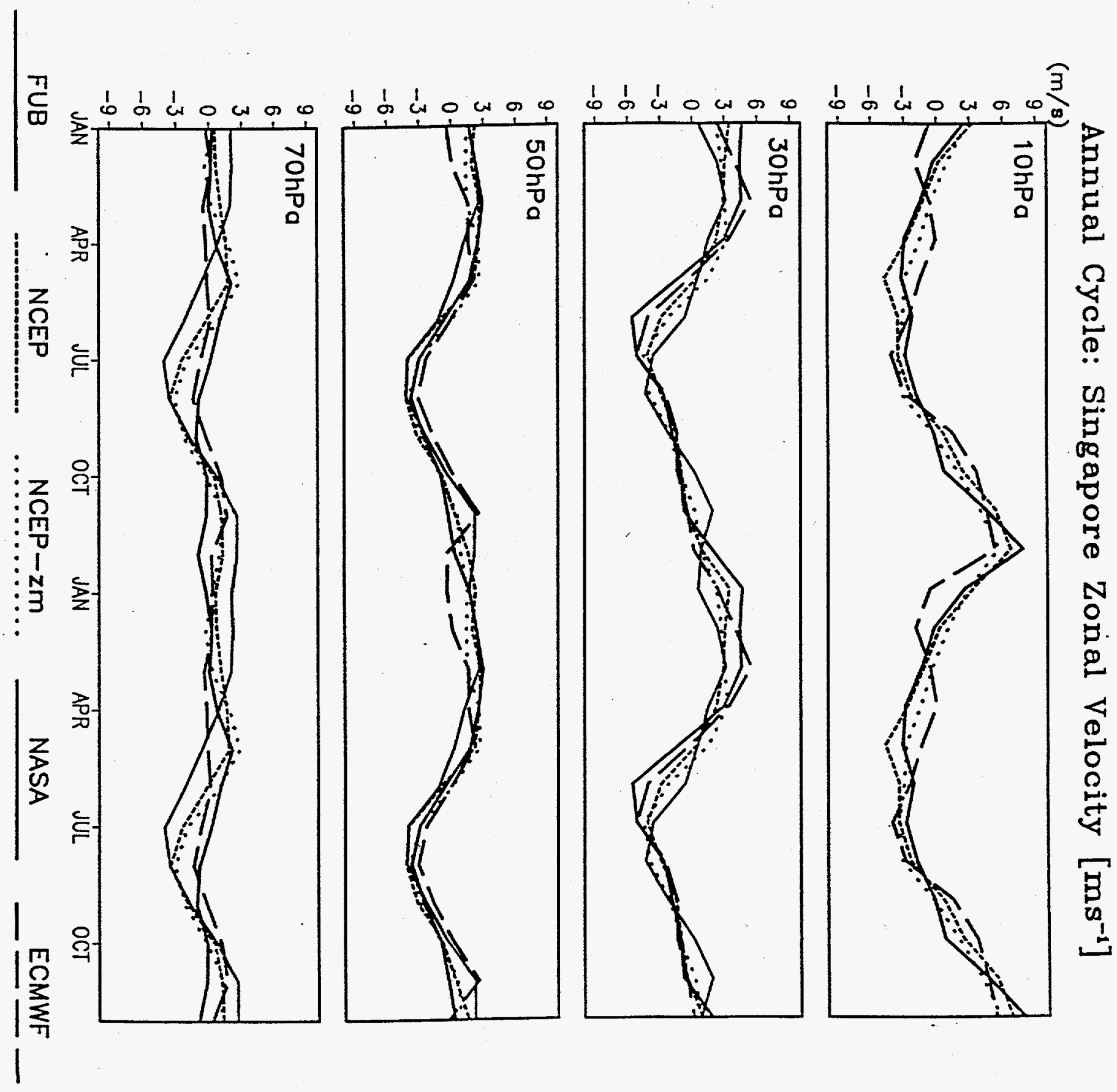

Fig. 5. The seasonal cycle, repeated twice, of the zonal wind at or near Singapore for rawinsonde observations (thick line), NCEP (short dashes), NASA (long dashes) and ERA (line) data. 

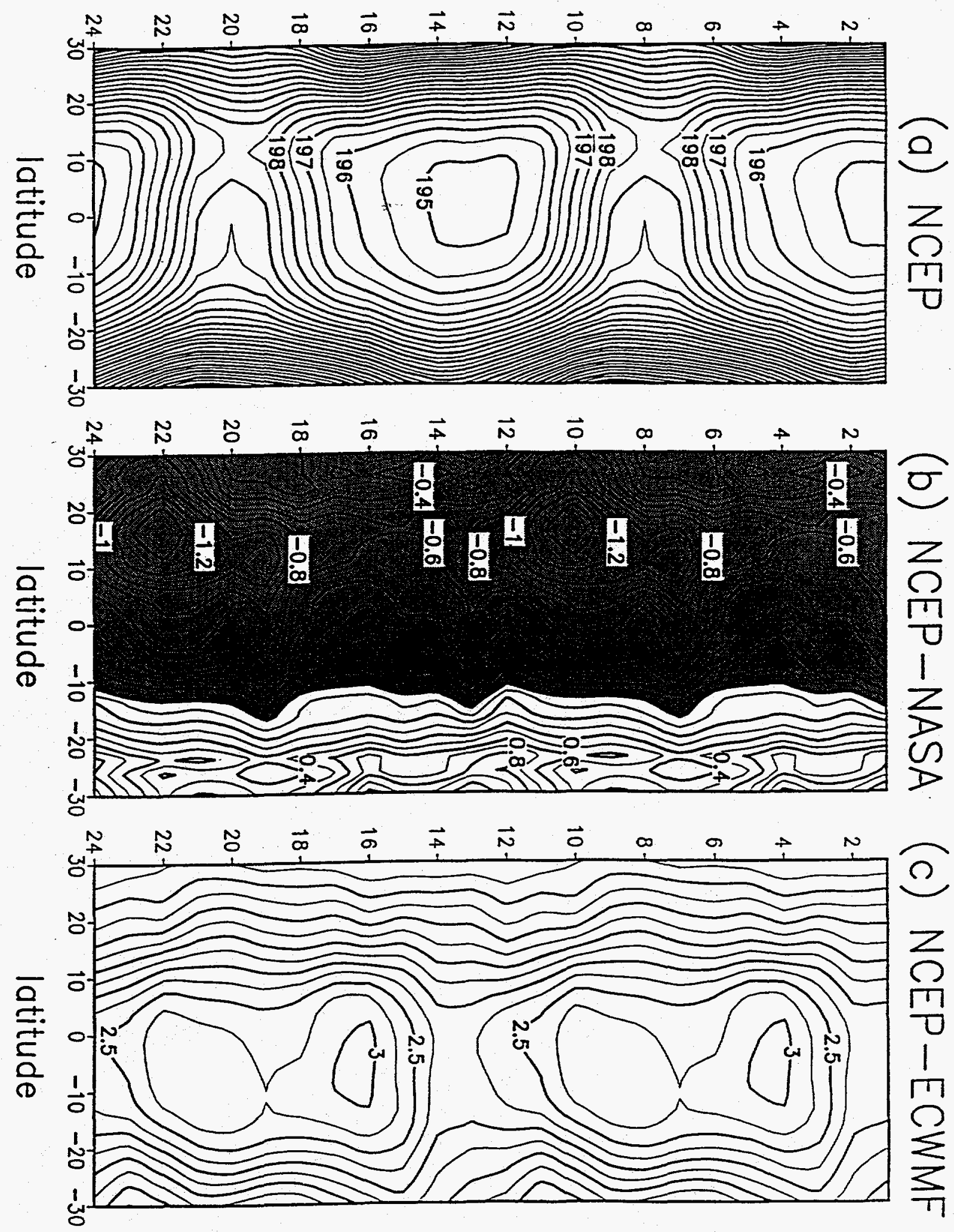

0
2
0
$\frac{1}{1}$
$\frac{1}{2}$
$\frac{\pi}{7}$

Fig. 6. The seasonal cycle, repeated twice, of (a) the $100 \mathrm{hPa}$ temperature $\left({ }^{\circ} \mathrm{K}\right.$; contour interval $0.5^{\circ} \mathrm{K}$ ) between $30^{\circ} \mathrm{N}$ and $30^{\circ} \mathrm{S}$ from the NCEP data, and the differences (b) NCEP-NASA (contour interval $0.1^{\circ} \mathrm{K}$ ) and (c) NCEP-ERA: shaded regions are where NASA data are warmer. The annual means were calculated from the longest possible record for each analysis. 

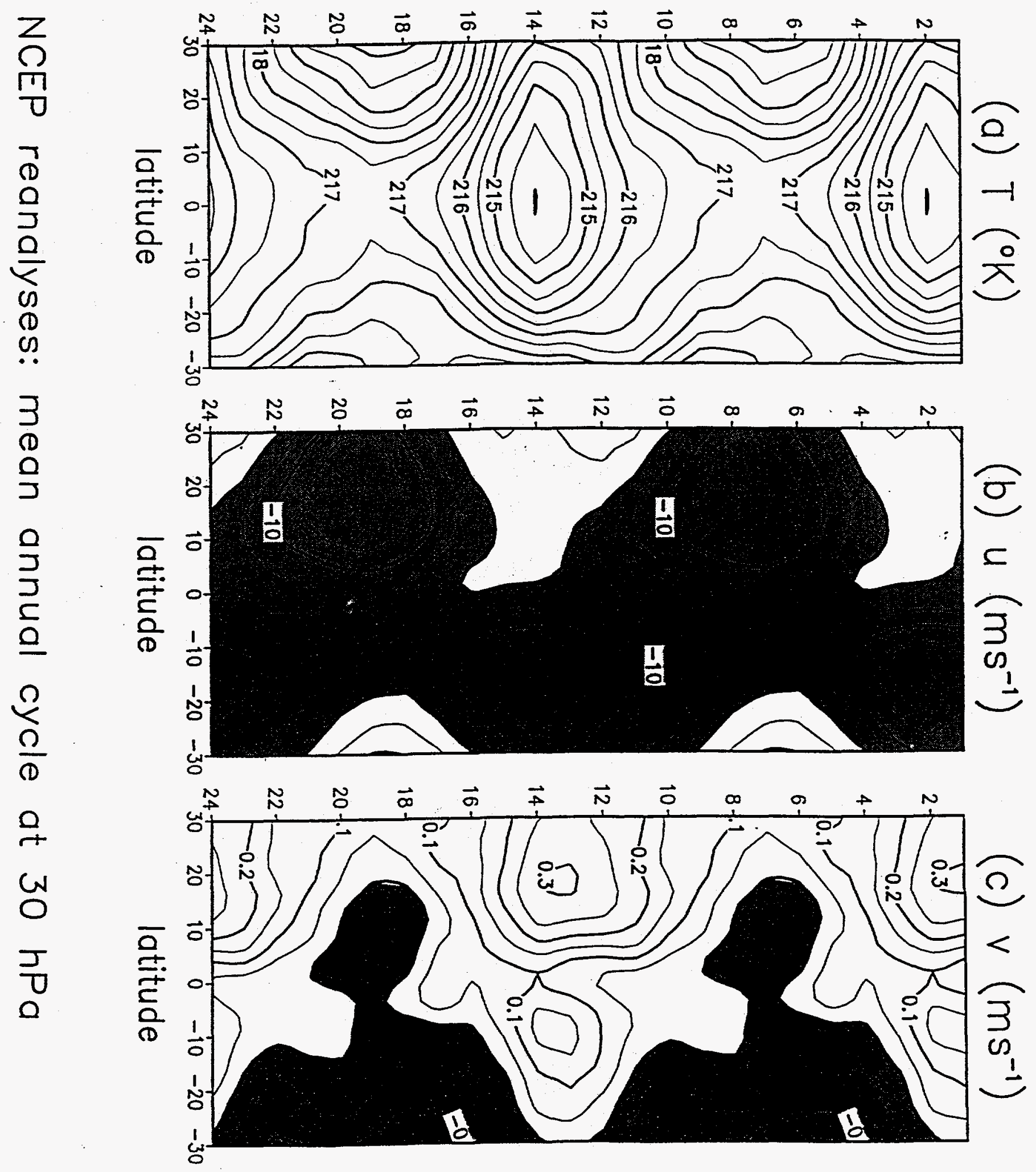

Fig. 7. The 17-year (Jan 1979-Dec 1995) mean seasonal cycle for the NCEP data, repeated twice, at $30 \mathrm{hPa}$ between $30^{\circ} \mathrm{N}$ and $30^{\circ} \mathrm{S}$, of (a) the zonal-mean temperature (contour interval $0.5^{\circ} \mathrm{K}$ ), (b) the zonal-mean zonal velocity (contour interval $5 \mathrm{~ms}^{-1}$ ), and (c) the zonal-mean meridional velocity (contour interval $0.05 \mathrm{~ms}^{-1}$ ). Shading in (b) and (c) denotes easterly or southward flow. 


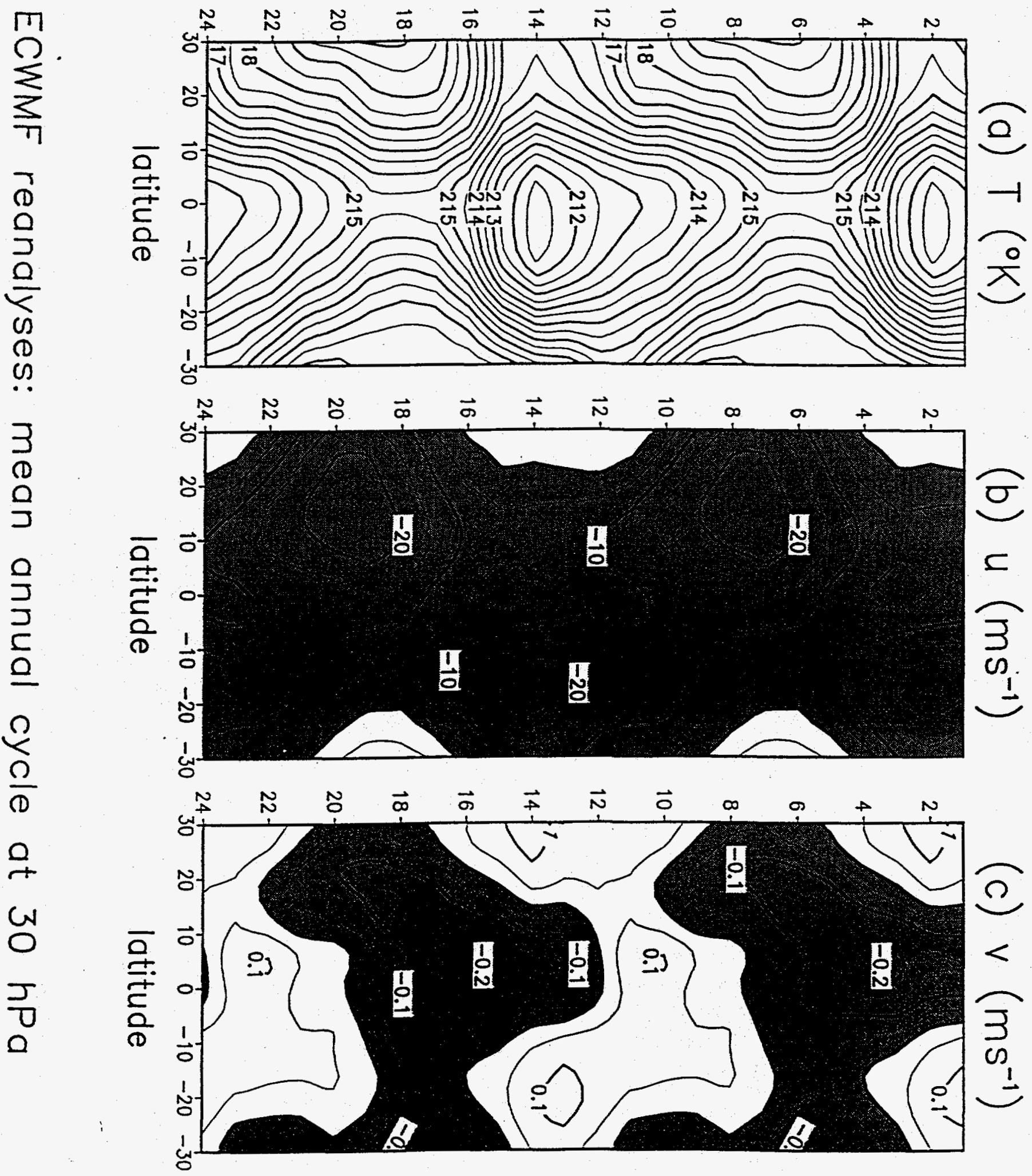

Fig. 8 As in Fig. 7, but for the ERA data except for 12 years (Jan 1979-Dec 1990). 
(a) T ( $\left.{ }^{\circ} \mathrm{K}\right), \mathrm{DJF}$

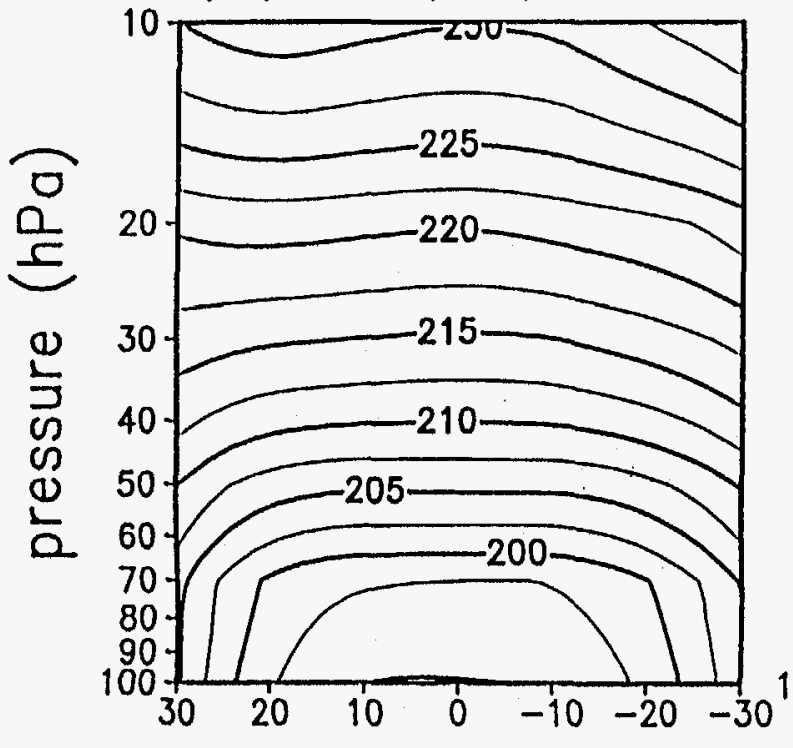

(b) $u\left(\mathrm{~ms}^{-1}\right)$, DJF

(c) $\vee\left(m^{-1}\right), D J F$
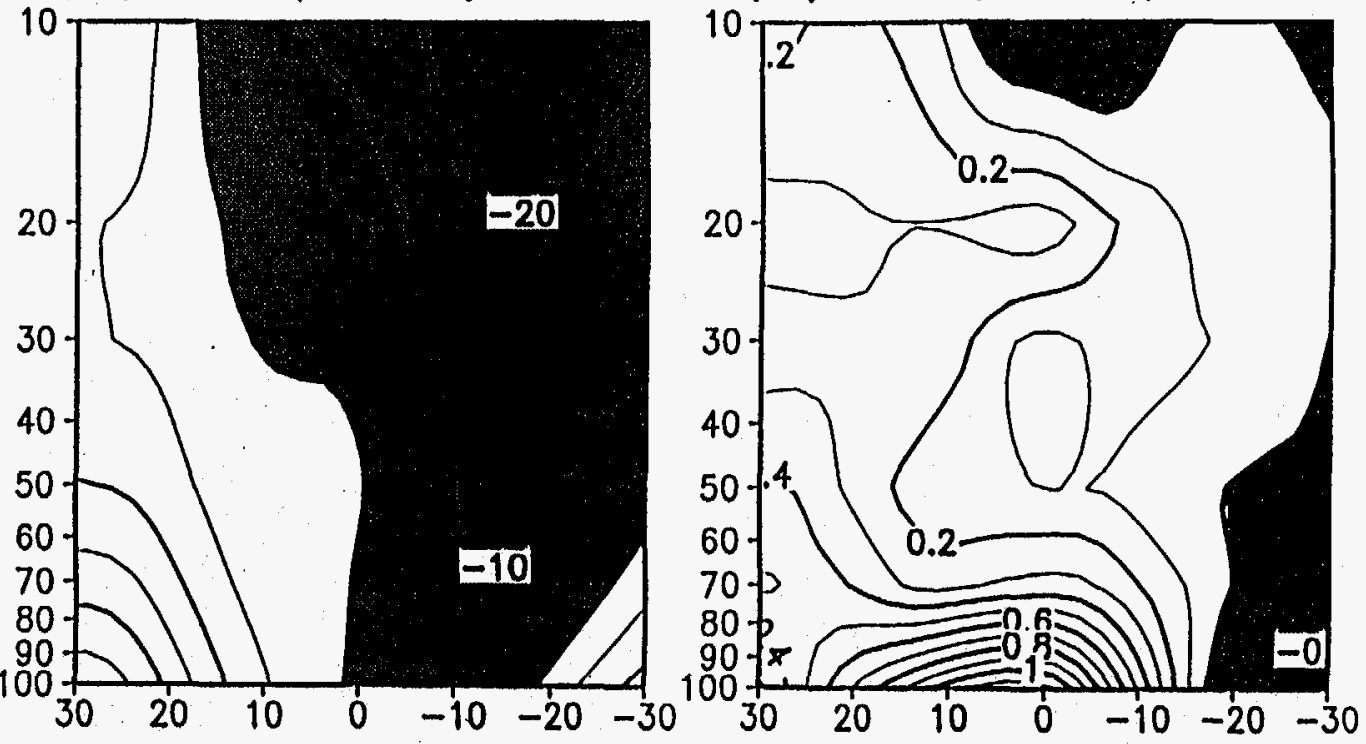

(d) $\mathrm{T}\left({ }^{\circ} \mathrm{K}\right), \mathrm{JJA}$

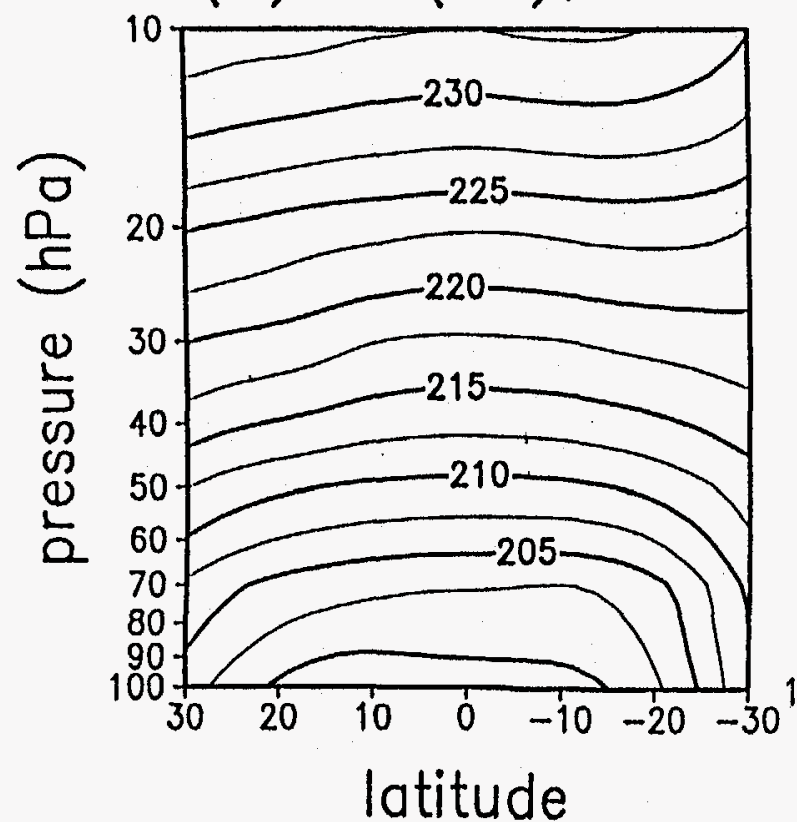

(e) $u\left(m s^{-1}\right), J J A$

$(\mathrm{f}) \vee\left(\mathrm{ms}^{-1}\right)$, JJA

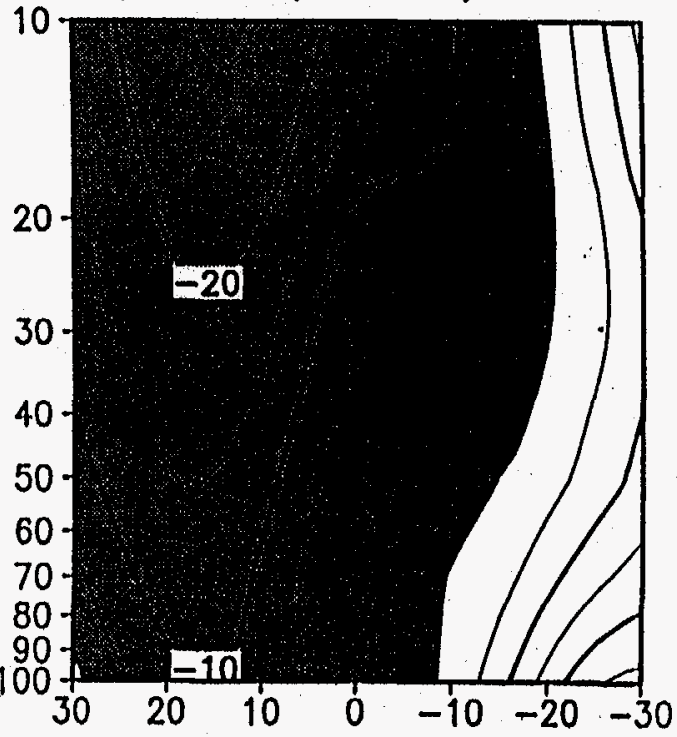

latitude

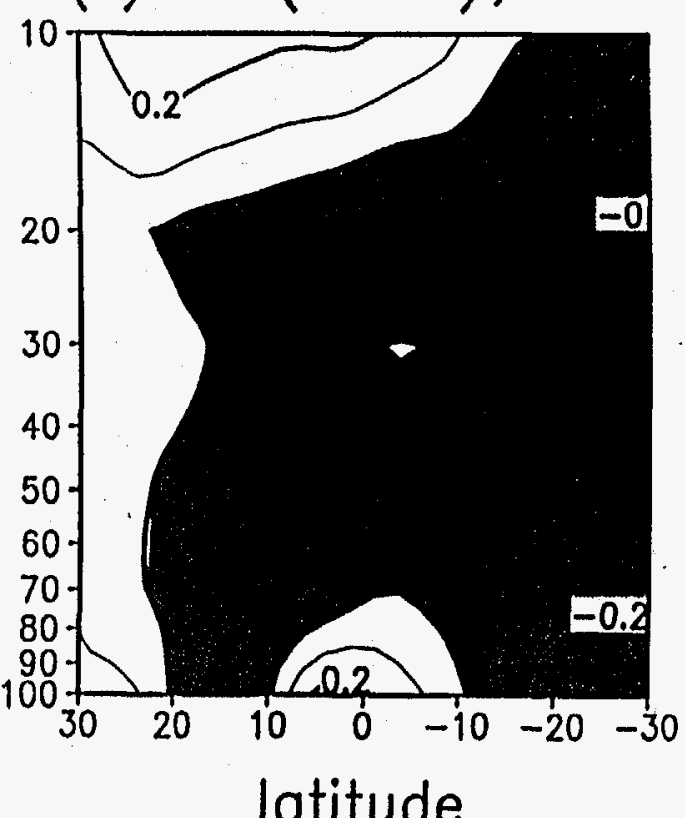

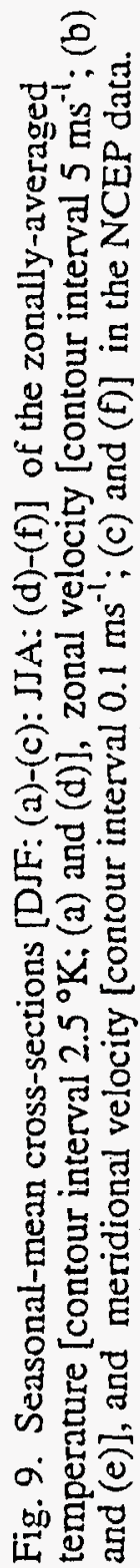

NCEP reanalyses: seasonal means in the tropical lower stratosphere 
$m$ pressure $(\mathrm{hPa})$

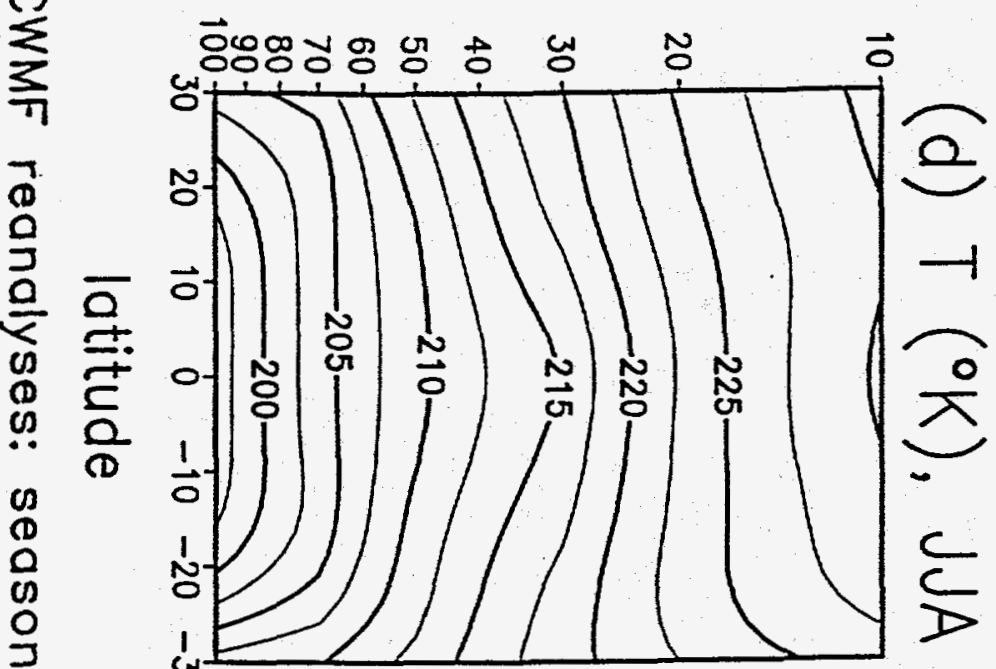

을

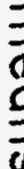

了

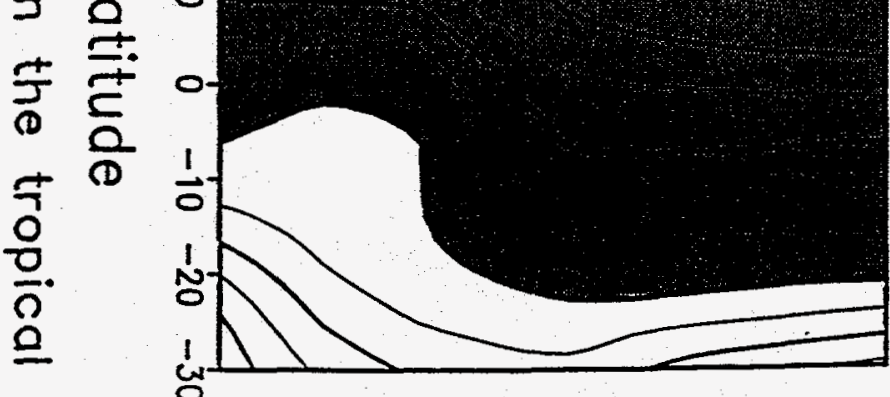

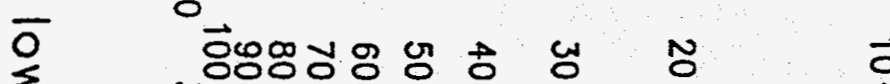

主

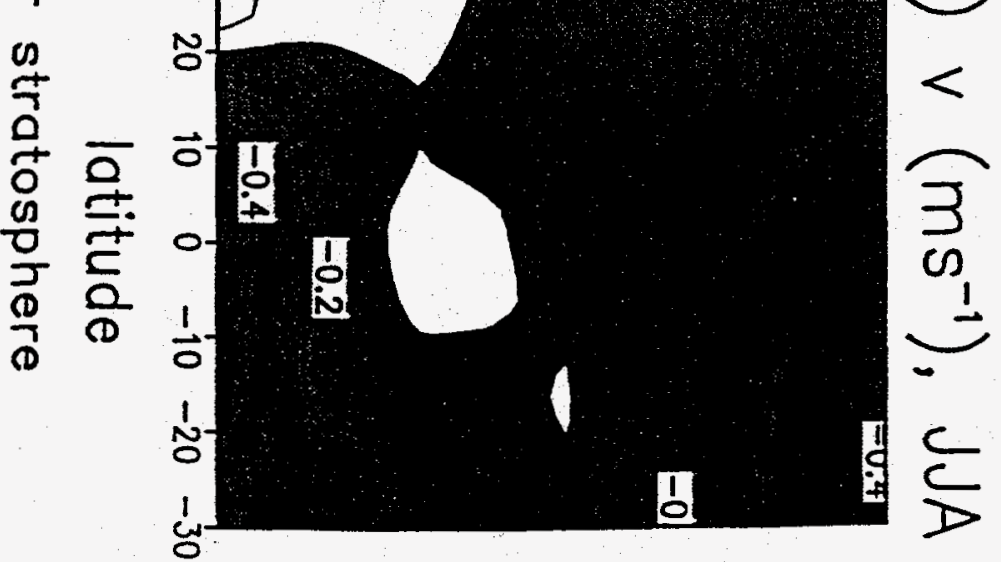

$\overrightarrow{0}$

$\subset$

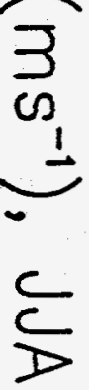

$\overrightarrow{0}$ pressure $(\mathrm{hPa})$

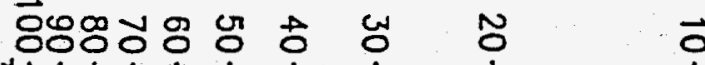

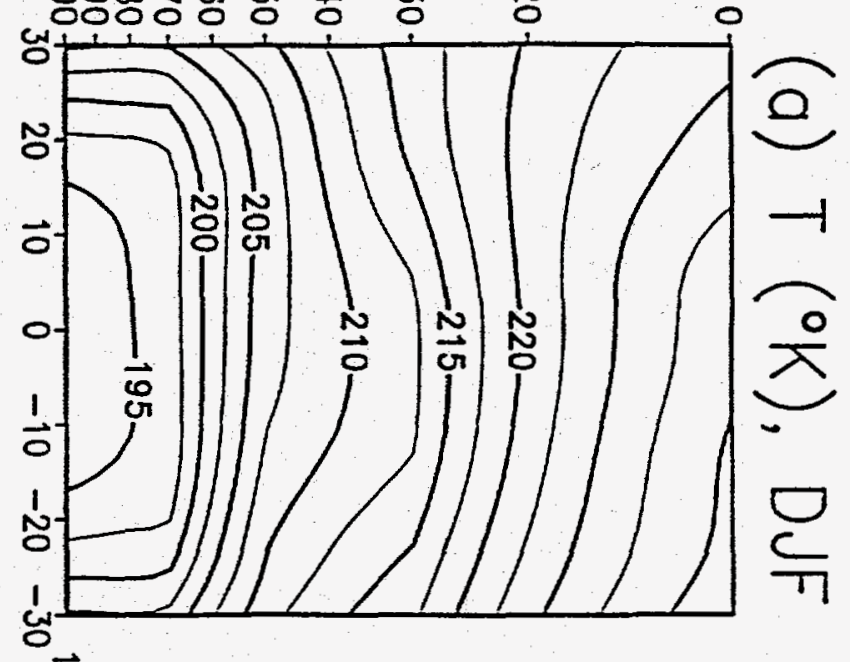

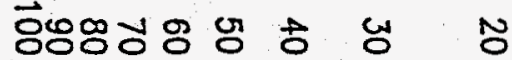

$\overrightarrow{0}$

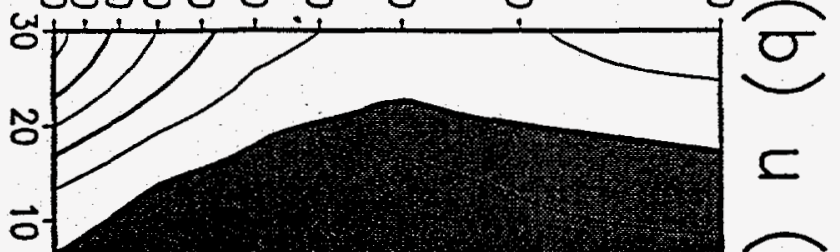

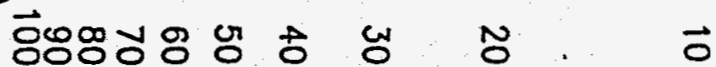

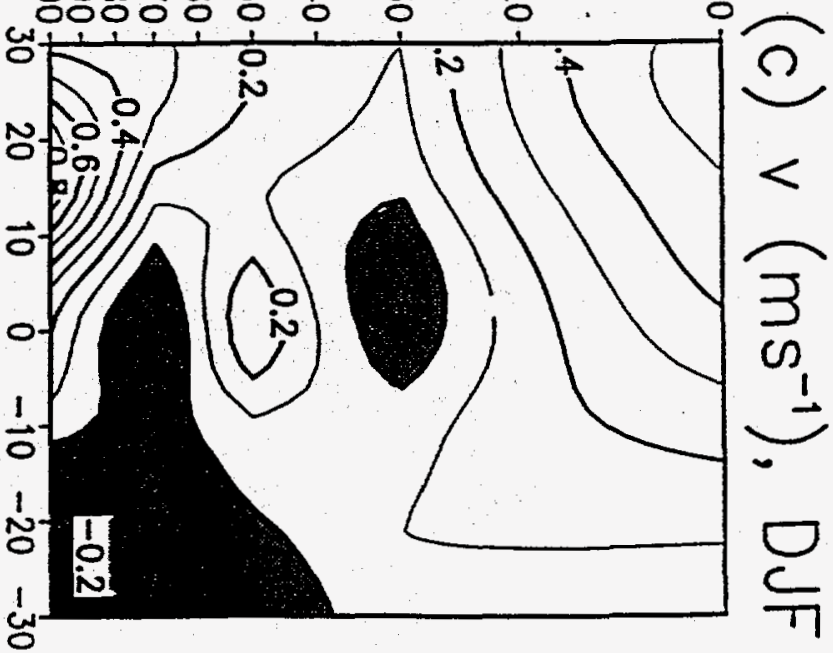

Fig. 10. As in Fig. 9, but for the ERA data. 

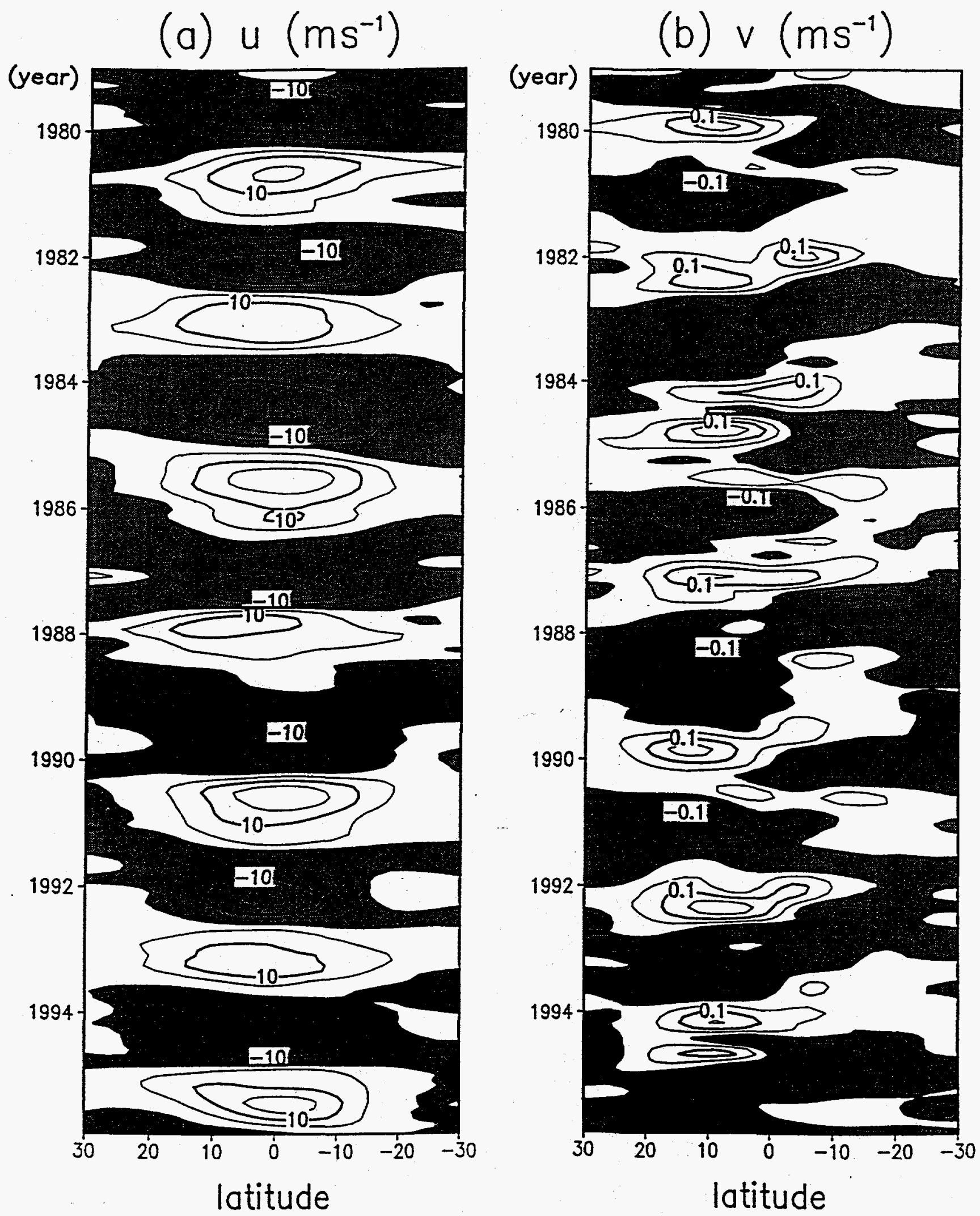

NCEP reanalyses: Dev. from mean ann. cycle at $30 \mathrm{hPa}$

Fig. 11. Monthly- and zonal-means of the $30 \mathrm{hPa}$ wind in the NCEP analyses with the 17-year mean annual cycle removed. (a) The zonal wind (contour interval $5 \mathrm{~ms}^{-1}$ ). (b) The meridional wind (contour interval $0.05 \mathrm{~ms}^{-1}$ ). Shaded values denote easterlies or southerlies, as appropriate. 

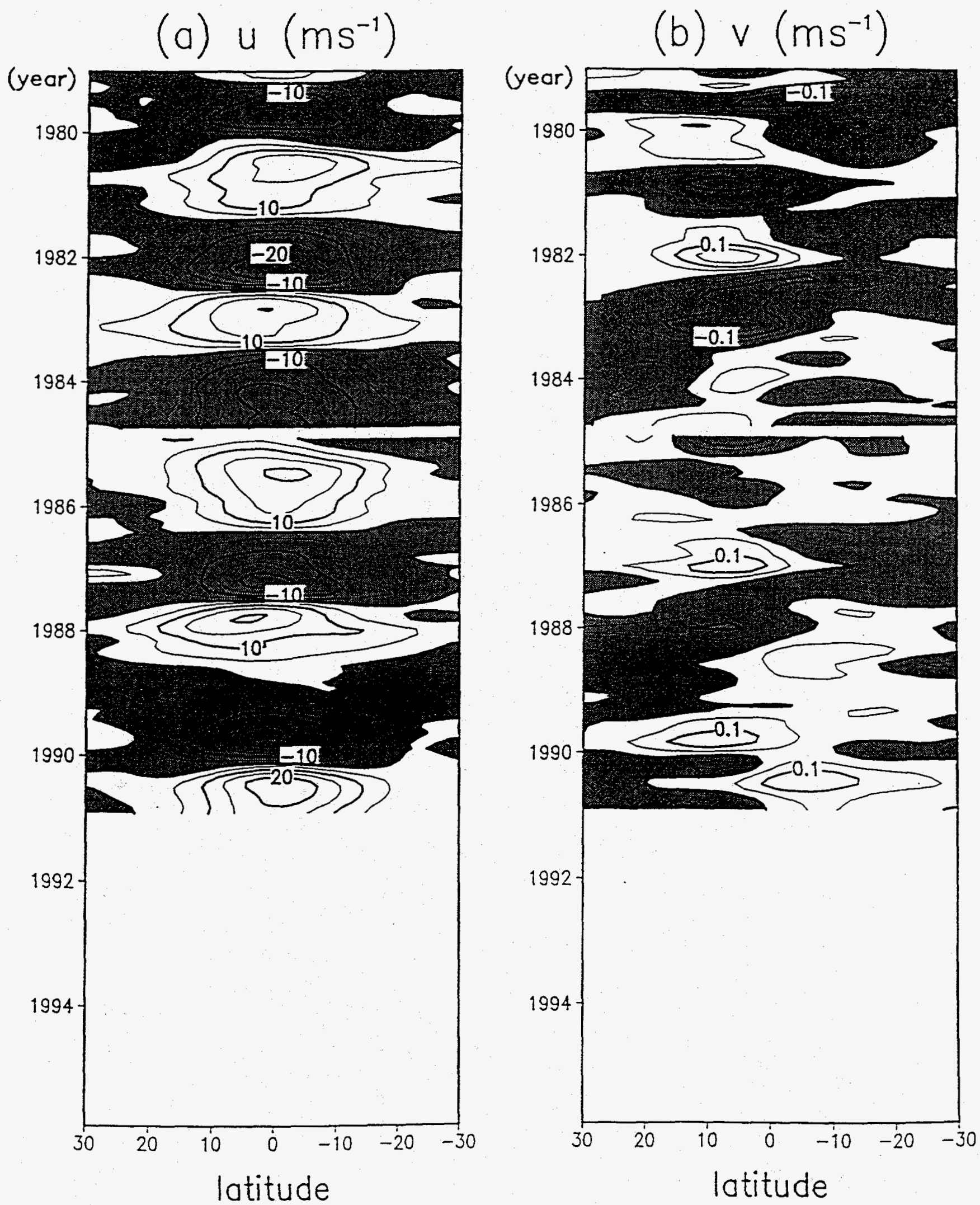

ECMWF reanalyses: Dev. from mean ann. cycle at $30 \mathrm{hPa}$

Fig. 12. As in Fig. 11, but for the ERA data. 

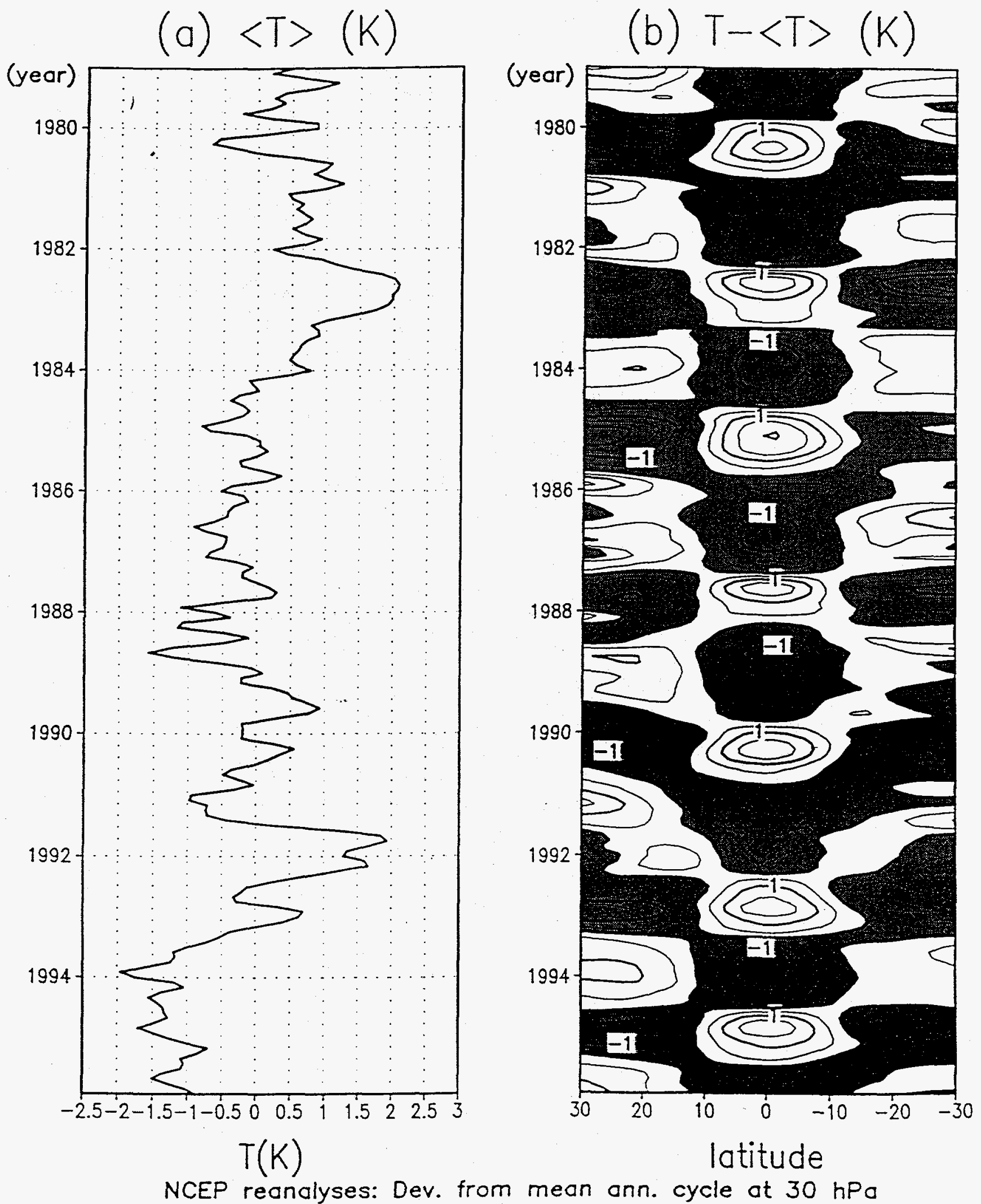

Fig. 13. The $30 \mathrm{hPa}$ temperature in the tropical stratosphere. (a) The mean between $30^{\circ} \mathrm{N}$ and $30^{\circ} \mathrm{S}$ between January 1979 and December 1995. (b) The latitudinal structure, with the mean annual cycle and the tropical mean in panel (a) removed (contour interval $1^{\circ} \mathrm{C}$, negative deviations shaded), with the 17-year mean annual cycle removed from the zonally-averaged NCEP data. Shaded regions denote negative values. 

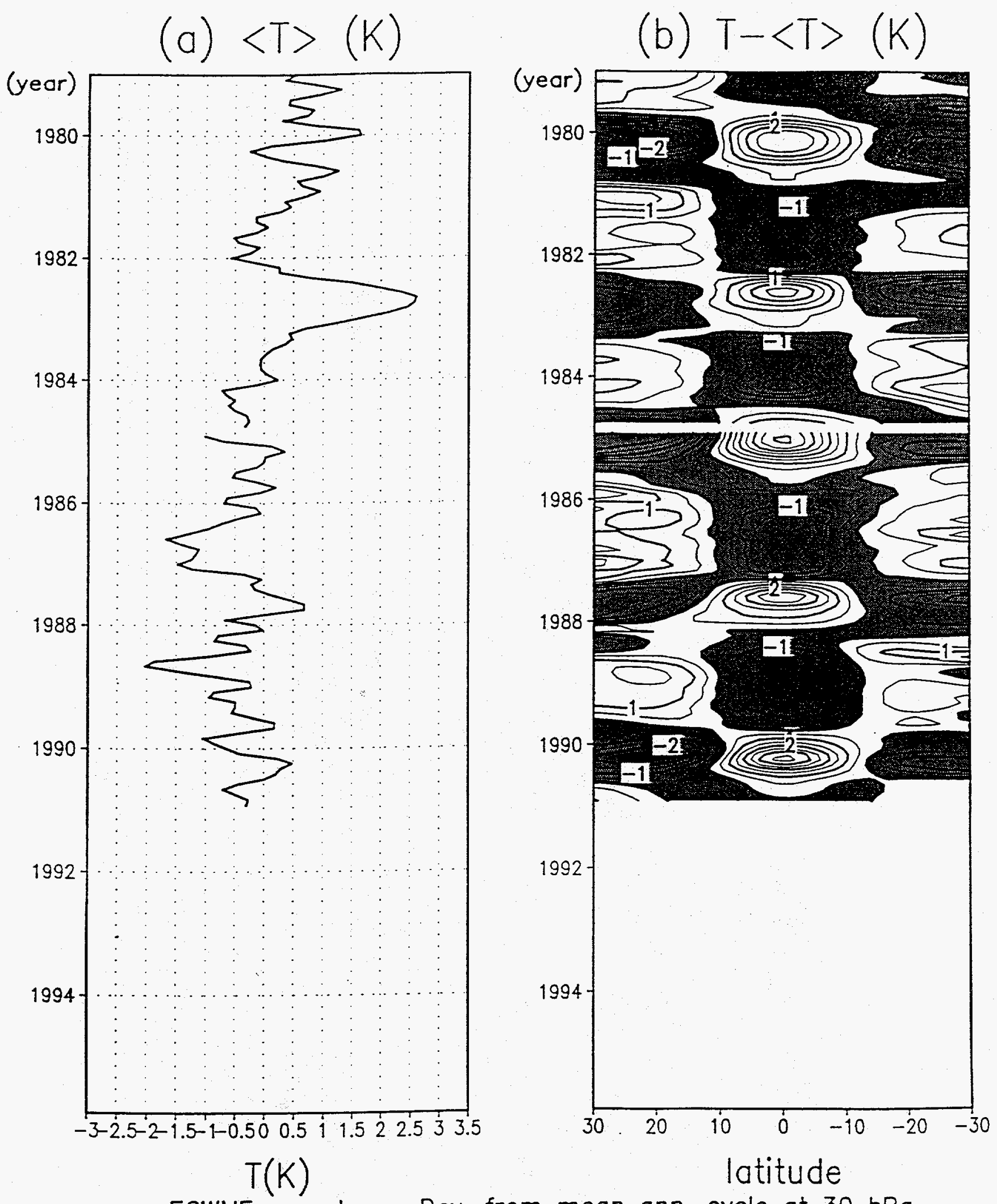

ECWMF reanalyses: Dev. from mean ann. cycle at $30 \mathrm{hPa}$

Fig. 14. As in Fig. 13, but for the ERA data. 

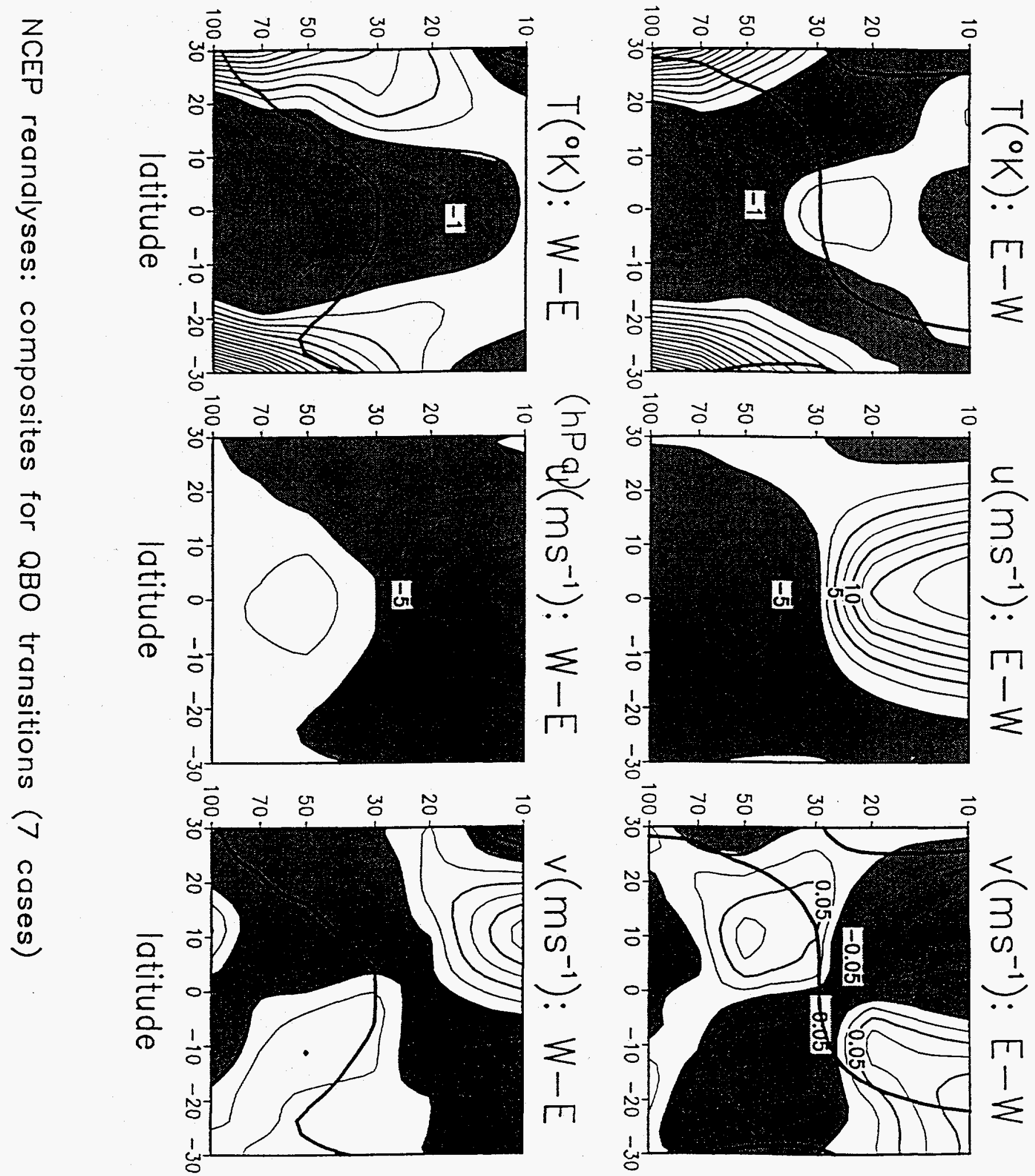

Fig. 15. Composites of the QBO for the NCEP data, based on the transitions at $30 \mathrm{hPa}$. Left: the temperature anomalies $\left({ }^{\circ} \mathrm{C}\right.$, contour interval $\left.0.5^{\circ} \mathrm{C}\right)$ with the tropical mean at each level subtracted. Middle: the dese-asonalized zonal wind $\left(\mathrm{ms}^{-1}\right.$, contour interval $\left.2.5 \mathrm{~ms}^{-1}\right)$. Right, the deseasonalized meridional velocities $\left(\mathrm{ms}^{-1}\right.$, contour interval $0.025 \mathrm{~ms}^{-1}$ ) with the meridional flow at each level over the tropics subtracted. These were calculated from the seven transitions listed for each case in Table 2. 


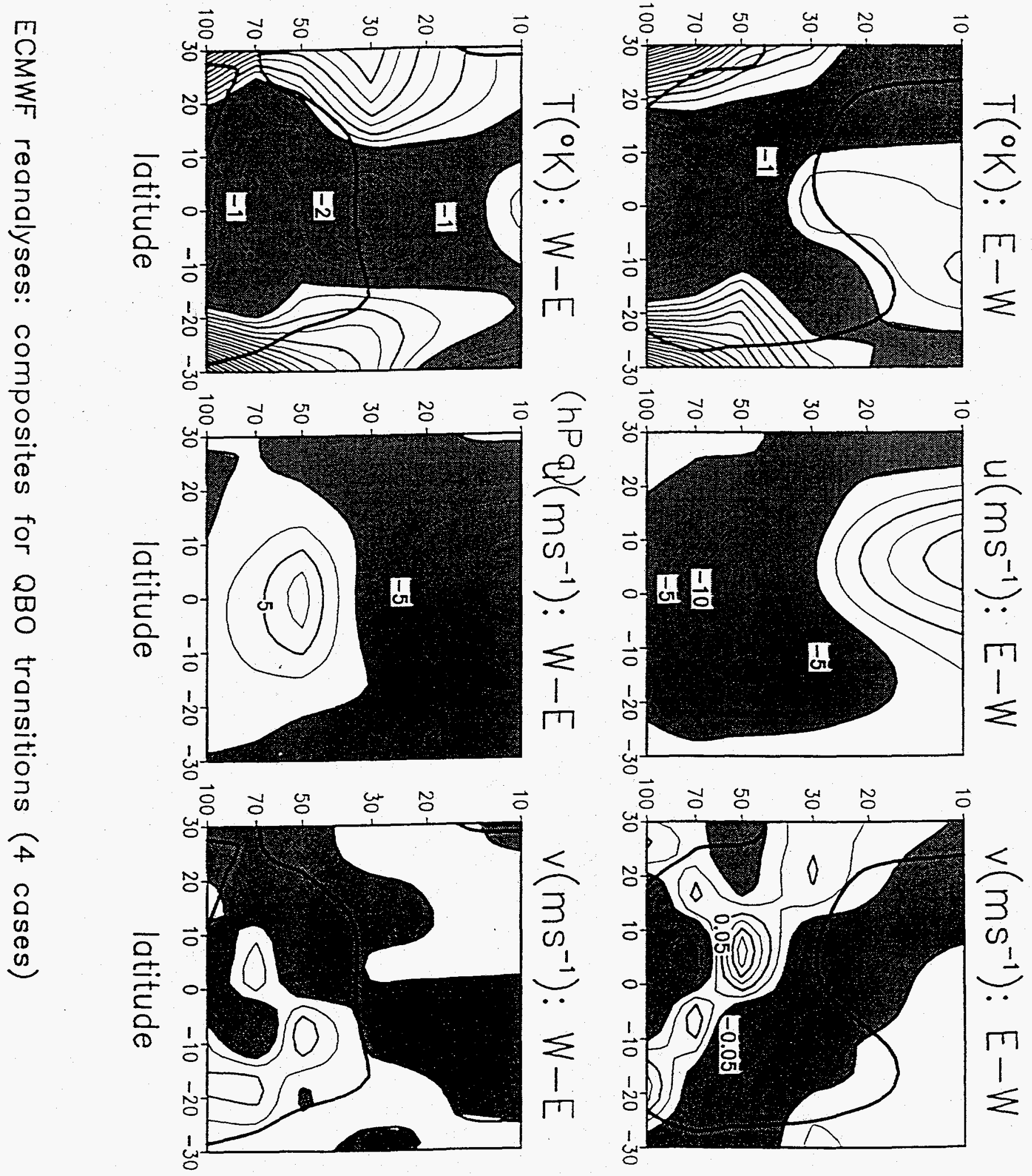

Fig. 16. As in Fig. 15, but for the ERA data. 


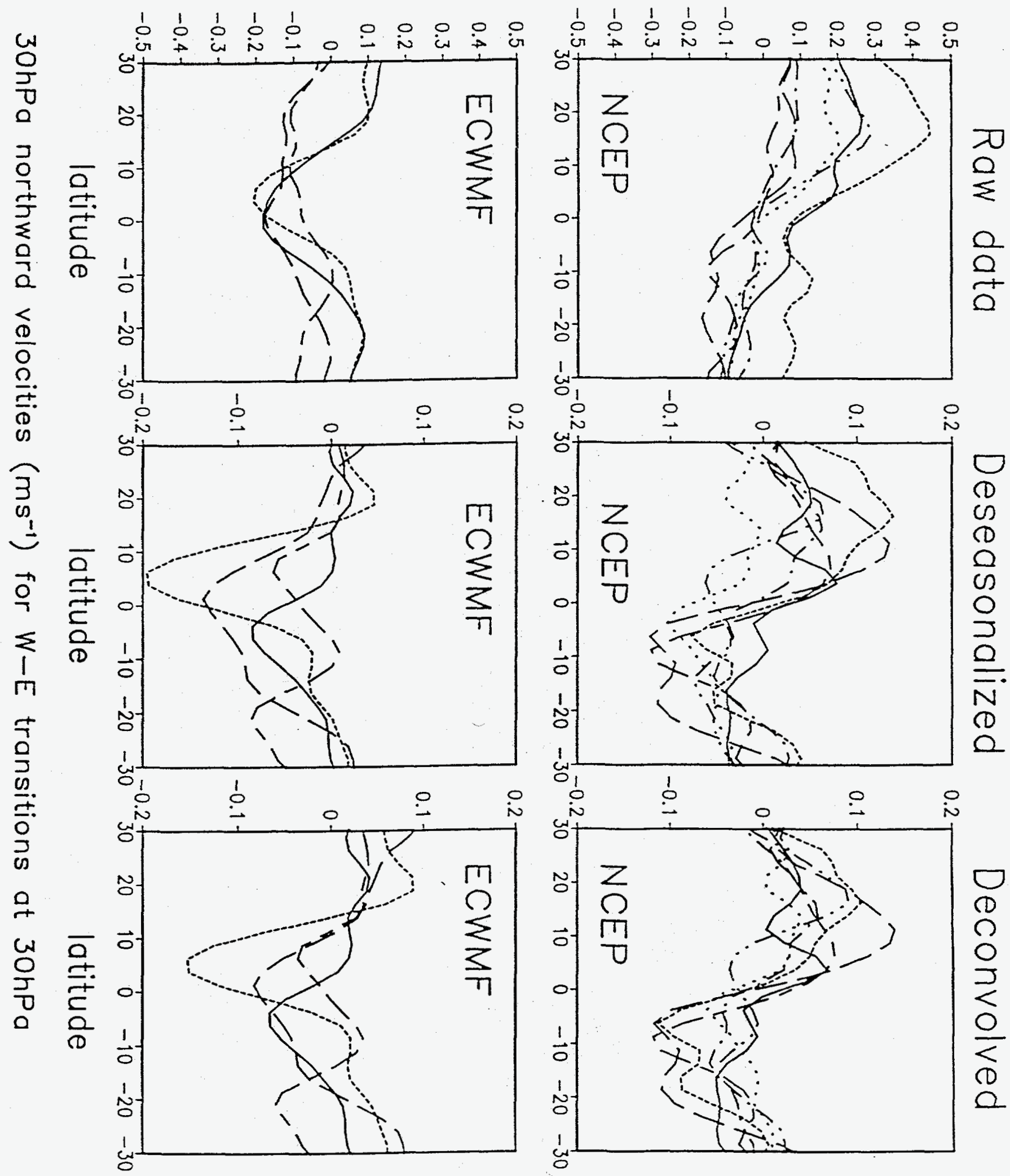

Fig. 17. The latitudinal structure of $v(30 \mathrm{hPa})$ for each of the $\mathrm{W}-\mathrm{E} \mathrm{QBO}$ transitions at $30 \mathrm{hPa}$ for the NCEP data (top) and the ERA data (bottom). Left: the raw data. Middle: the deseasonalized data. Right: the deconvoluted data, as used in Figs. 15 an 16. These are deseasonalized and the mean in the range $30^{\circ} \mathrm{S}-30^{\circ} \mathrm{N}$ is removed. 


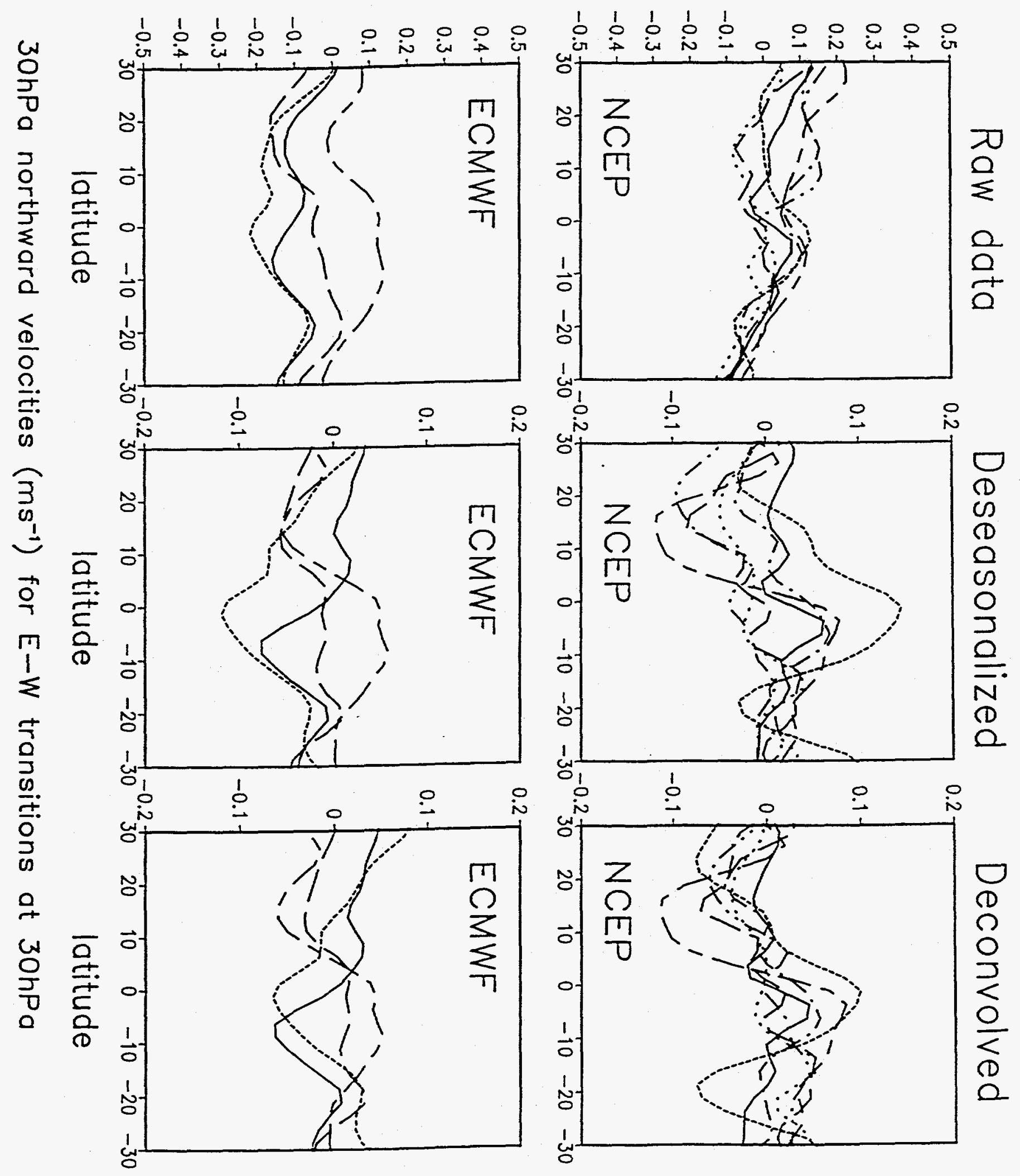

Fig. 18. As in Fig. 17, but for the E-W QBO transitions at $30 \mathrm{hPa}$. 


\section{PCMDI REPORTS}

\begin{tabular}{|c|c|c|c|}
\hline Number & Title & Author(s) & Date \\
\hline 1 & The Validation of Atmospheric Model & W.L. Gates & March 1992 \\
\hline 2 & $\begin{array}{l}\text { Analysis of the Temporal Behavior of } \\
\text { Tropical Convection in the } \\
\text { ECMWF Model }\end{array}$ & $\begin{array}{l}\text { J.M. Slingo } \\
\text { K.R. Sperber } \\
\text { J.-J. Morcrette } \\
\text { G.L. Potter }\end{array}$ & April 1992 \\
\hline 3 & $\begin{array}{l}\text { The Effect of Horizontal Resolution } \\
\text { of Ocean Surface Heat Fluxes in } \\
\text { the ECMWF Model }\end{array}$ & $\begin{array}{l}\text { P.J. Gleckler } \\
\text { K.E. Taylor }\end{array}$ & July 1992 \\
\hline 4 & $\begin{array}{l}\text { Behavior of an Ocean General } \\
\text { Circulation Model at Four } \\
\text { Different Horizontal Resolutions }\end{array}$ & C. Covey & August 1992 \\
\hline 5 & $\begin{array}{l}\text { The Effects of Sampling Frequency } \\
\text { on the Climate Statistics of the } \\
\text { ECMWF General Circulation } \\
\text { Model }\end{array}$ & $\begin{array}{l}\text { T.J. Phillips } \\
\text { W.L. Gates } \\
\text { K. Arpe }\end{array}$ & September 1992 \\
\hline 6 & $\begin{array}{l}\text { Sensitivity of Dynamical Quantities to } \\
\text { Horizontal Resolution in a Climate } \\
\text { Simulation with the ECMWF } \\
\text { Atmospheric General Circulation } \\
\text { Model (Cycle 33) }\end{array}$ & J.S. Boyle & October 1992 \\
\hline 7 & $\begin{array}{l}\text { AMIP: The Atmospheric Model } \\
\text { Intercomparison Project }\end{array}$ & W.L. Gates & December 1992 \\
\hline 8 & $\begin{array}{l}\text { The Impact of Horizontal Resolution } \\
\text { on Moist Processes in the ECMWF } \\
\text { Model }\end{array}$ & $\begin{array}{l}\text { T.J. Phillips } \\
\text { L.C. Corsetti } \\
\text { S.L. Grotch }\end{array}$ & January 1993 \\
\hline
\end{tabular}


9 A Modeling Perspective on Cloud Radiative Forcing

10

The Use of General Circulation Models in Detecting Climate Change Induced by Greenhouse Gases

11 Preliminary Validation of the Low Frequency Variability of Tropospheric Temperature and Circulation Simulated for the AMIP by the ECMWF Model

12 Simulation of the Indian and EastAsian Summer Monsoon in the ECMWF Model: Sensitivity to Horizontal Resolution

13. Statistical Intercomparison of Global Climate Models: A Common Principal Component Approach

14 Ocean Variability and its Influence on the Detectability of Greenhouse Warming Signals
G.L. Potter

J.M. Slingo

J.-J. Morcrette

L. Corsetti

B.D. Santer

U. Cubasch

U. Mikolajewicz

G. Hegerl

J.S. Boyle
April 1993

February 1993

March 1993

March 1993
K.R. Sperber

S. Hameed

G.L. Potter

J.S. Boyle

S.K. Sengupta

J.S. Boyle 
15 Cloud-Radiative Effects on Implied

Oceanic Energy Transports as

Simulated by Atmospheric General

Circulation Models
16 DRS User's guide

17 The PCMDI Visualization and

Computation System (VCS): A

Workbench for Climate Data

Display and Analysis

18 A Summary Documentation of the AMIP Models

19 Global Ocean Circulation and Equator-Pole Heat Transport as a Function of Ocean GCM Resolution

20 The Northern Wintertime Divergence Extrema at $200 \mathrm{hPa}$ and Surface Cyclones as Simulated in the AMIP Integration of the ECMWF General Circulation Model
P.J. Gleckler

March 1994

D.A. Randall

G. Boer

R. Colman

M. Dix

V. Galin

M. Helfand

J. Kiehl

A. Kitoh

W. Lau

X.-Z. Liang

V. Lykossov

B. McAvaney

K. Miyakoda

S. Planton

R. Drach

R. Mobley

March 1994

D.N. Williams

R.L. Mobley

March 1994

T.J. Phillips

April 1994

C. Covey

June 1994

J.S. Boyle

November 1994 
21 Towards the Detection and

B.D. Santer

January 1995

Attribution of an Anthropogenic

Effect on Climate

K.E. Taylor

T.M.L. Wigley

J.E. Penner

P.D. Jones

U. Cubasch

22 The Effect of Horizontal Resolution

G.L. Potter

July 1995

on Cloud Radiative Forcing in the ECMWF Model

23 Intercomparison of the Spectral

Characteristics of $200 \mathrm{hPa}$ Kinetic

J.S. Boyle

August 1995

Energy in Some AMIP Simulations

24 Documentation of the AMIP Models

on the World Wide Web

T.J. Phillips

August 1995

25 Estimates of Zonally Averaged

Tropical Diabatic Heating in AMIP

GCM Simulations

26 Uncertainties in Global Ocean Surface

P.J. Gleckler

Nov 1995

Heat Flux Climatologies Derived

from Ship Observations

B.C. Weare

August 1995

J.S. Boyle

27 A Search for Human Influences on the

Thermal Structure of the

Atmosphere

B.D. Santer

K.E. Taylor

T.M.L. Wigley

P.D. Jones

D.J. Karoly

J.F.B. Mitchell

A.H. Oort

J.E. Penner

V. Ramaswamy

M.D. Schwarzkopf

R.J. Stouffer

S. Tett

Nov 1995 

Model Simulations Associated with the Atmospheric Model Intercomparison Project

Dec 1995 in AMIP Simulations Circulation for AMIP Simulations 